\title{
Environmental variability facilitates coexistence within an alcid community at sea
}

\author{
J. Christopher Haney ${ }^{1, *}$, Amy E. S. Schauer ${ }^{2}$ \\ 'Alaska Fish and Wildlife Research Center, U. S. Fish and Wildlife Service, 1011 E. Tudor Rd, Anchorage, Alaska 99503, USA \\ ${ }^{2}$ Institute of Marine Science, University of Alaska, Fairbanks, Alaska 99775, USA
}

\begin{abstract}
We examined coexistence at sea among 7 taxa of diving, wing-propelled seabirds (Alcidae) in the genera Aethia, Uria, Cepphus, and Fratercula. Species abundances were measured simultaneously with a suite of environmental factors in the northern Bering Sea, Alaska, USA; data from 260 adjacent and non-adjacent sites occupied by alcids foraging of fshore near breeding colonies were then subjected to principal component analysis (PCA). We used PCA to group redundant environmental descriptors, to identify orthogonal axes for constructing a multi-dimensional niche, and to differentiate species associations within niche dimensions from species associations among niche dimensions. Decomposition of the correlation matrix for 22 environmental and 7 taxonomic variables with PCA gave 14 components (10 environmental and 4 species interactions) that retained $90 \%$ of the original available variance. Alcid abundances (all species) were most strongly correlated with axes representing tidal stage, a time-area interaction (due to sampling layout), water masses, and a temporal or intra-seasonal trend partially associated with weather changes. Axes representing tidal stage, 2 gradients in macro-habitat (Anadyr and Bering Shelf Water masses), the micro-habitat of the sea surface, and an air-sea interaction were most important for detecting differences among species within niche dimensions. Contrary to assumptions of competition, none of 4 compound variables describing primarily species-interactions gave strong evidence for negative associations between alcid taxa sharing similar body sizes and feeding requirements. This exploratory analysis supports the view that alcids may segregate along environmental gradients at sea. But in this community, segregation was unrelated to foraging distance from colonies, in part because foraging 'substrate' was highly variable in structure, location, and areal extent. We contend that coexistence within this seabird group is facilitated via expanded niche dimensions created from a complex marine environment.
\end{abstract}

KEY WORDS: Alcidae (Ave) $\cdot$ Coexistence $\cdot$ Community structure $\cdot$ Marne birds $\cdot$ Niche definition

\section{INTRODUCTION}

Investigations of coexistence among jointly occurring taxa, and processes facilitating such coexistence, form the cornerstone to the field of community ecology. Community structure has been variously attributed to resource abundance, predation, competition, habitat structure, and stochastic variation in the environment (e.g. Wiens 1977, Sano 1990, papers in Strong et al. 1984, and Diamond \& Case 1986). The relative importance and existence of these factors, however, have remained contentious enough to lead some to conclude

- Present address: Wildlife Technology Program, School of Forest Resources, Pennsylvania State University, College Place, DuBois, Pennsylvania 15801, USA. that belief, rather than reason, drives arguments promoting the various theories (Wolda 1989).

Seabird communities provide a rich opportunity to observe many species in close interaction. Population regulation of seabirds has been perceived historically to be very closely tied to resource abundance (Ashmole 1963, Birkhead \& Furness 1985), especially during the breeding season (Lack 1966, 1967). Given their dual lifestyles (part terrestrial, part marine), seabird associations differ notably from many substratedominated communities (Ribic \& Ainley 1988/1989). Therefore, several structuring mechanisms present in other marine vertebrates are not readily invoked, such as 'lottery' colonization by juvenile and larval recruits (Sale 1978, 1980) and nonequilibrium reduction of carrying capacities due to predation and recruit avail- 
ability (Wellington \& Victor 1984, Doherty \& Williams 1988). During the breeding season, adult seabirds must obtain food for themselves and their young within restricted commuting distances, leading to evidence of locally depleted food supplies (Birt et al. 1987) which may place limits on population size (Furness \& Birkhead 1984, Birkhead \& Furness 1985, Cairns 1992). Seabirds with similar morphology and feeding styles segregate by marine foraging zone (Weimerskirch et al. 1988). Access to nesting space at adjacent colonies can be limited (Ainley \& Boekelheide 1990, Piatt et al. 1990), leading to suggestions that resource competition extends to marine habitats as well. Finally, non-linear responses to shared prey, arising from differences in body size or foraging style, has been promoted as a mechanism that facilitates coexistence among seabirds (Piatt 1990).

Because of their dominance by numbers and biomass in the northern hemisphere, primarily wing-propelled diving habits, and use of subsurface waters for foraging, the Alcidae prompted some of the earliest queries into resource use, overlap and partitioning (e.g. Bédard 1969a, b, 1976, Cody 1973). Aside from taxonomy (Strauch 1985), several traits unite alcids as a group: they feed solitarily, they use partly opened wings for underwater propulsion, and they capture small, individual prey in marine environments (Bédard 1969a, p. 169). Alcids often nest in multi-species colonies. Resource competition could conceivably be great during the breeding season because adults' ability to provision chicks will limit foraging distances, thereby concentrating birds within restricted areas. Even though the ecology, behavior, and breeding biology of alcids are better studied than any other taxon of seabirds (papers and references in Nettleship \& Birkhead 1985, Vermeer et al. 1987, Flint \& Golovkin 1990, Sealy 1990), the nature and magnitude of species interactions within this group still remain little known in the marine realm (Hunt et al. 1993).

Body morphology (Bédard 1969b, Spring 1971), diet (Vermeer et al. 1987, Harrison 1990), submarine foraging behavior (Duffy et al. 1987), response to prey aggregations (Piatt 1990), and diving depth (Piatt \& Nettleship 1985, Burger \& Simpson 1986) have all been used to detect or advocate partitioning among alcids. Most studies have examined single species (e.g. Hunt et al. 1990), species pairs (Bradstreet 1979, 1980, Birkhead \& Nettleship 1987, Erikstad \& Vader 1989) or single guilds (Bédard 1969b, c, Harrison 1990). Attempts to delimit coexistence among entire alcid communities have been rare. Typically only 1 resource axis is measured at a time (e.g. Haney 1991). Interpreting coexistence within a single resource dimension is fraught with problems, however, because overlap or segregation detected on any 1 axis may be mitigated by opposite trends along additional resource dimensions (cf. Cody 1973, Bédard 1976; see also Sano 1990. Schoener \& Adler 1991)

Cody (1973) claimed that competition resulted in alcids segregating by foraging distance from their colonies. Bédard (1976) questioned this interpretation and recommended further tasks for evaluating marine coexistence in this group, including: (1) the need for sophisticated oceanographic measurements given problems in reducing patterns to simple linear dimensions; (2) the expectation that spatial segregation should be expressed more clearly within groups of similar ecological types of alcids than without; (3) the placement of patterns into contexts of inter-regional differences in population size and 'representative' environmental variablity; and (4) the recognition that choice of scale could influence claims of segregation depending on the manner in which observations are sorted. Drawing on a species-rich community of alcids in the North Pacific Ocean, we conducted an analysis focusing mostly on the first 3 tasks, but we also discuss implications (and limitations) of scale. Our principal goal was to identify a limited number of resource dimensions likely to be important in more formal, longterm studies of alcid coexistence. After using a multivariate technique to reduce data complexity, we place our results into contexts of: (1) an expanded niche for seabirds (Ainley \& Boekelheide 1990); and (2) the masking effects that habitat affinities can have on detection of species associations (Schoener \& Adler 1991)

\section{STUDY AREA AND THE ALCID COMMUNITY}

Our study took place in the Anadyr Strait region of the northwestern Bering Sea, Alaska USA, between St. Lawrence Island and the Chukotka Peninsula of Russia (Fig. 1). The shallow topography of this continental shelf, strong horizontal advection, and exogenous resupply of nutrients combine to promote very high production along both pelagic and benthic pathways of the foodweb (McRoy et al. 1972, Coachman et al. 1975, Sambrotto et al. 1984, Grebmeier et al. 1988, Hansell et al. 1989, Highsmith \& Coyle 1990). This production in turn supports populations of both fish-and plankton-feeding seabirds that number into the millions (Sowls et al. 1978, Springer et al. 1987, 1989).

The Alcidae evolved and radiated within the North Pacific Ocean (Bédard 1969a), with the center of diversity residing in the Bering Sea. Including range extensions (e.g. Alle alle; Day et al. 1988) and small populations of other species that may breed (Cepphus grylle, C. carbo and Brachyramphus brevirostris; see Konyukhov 1990, 1992, Dinets 1992), the islands, marginal 


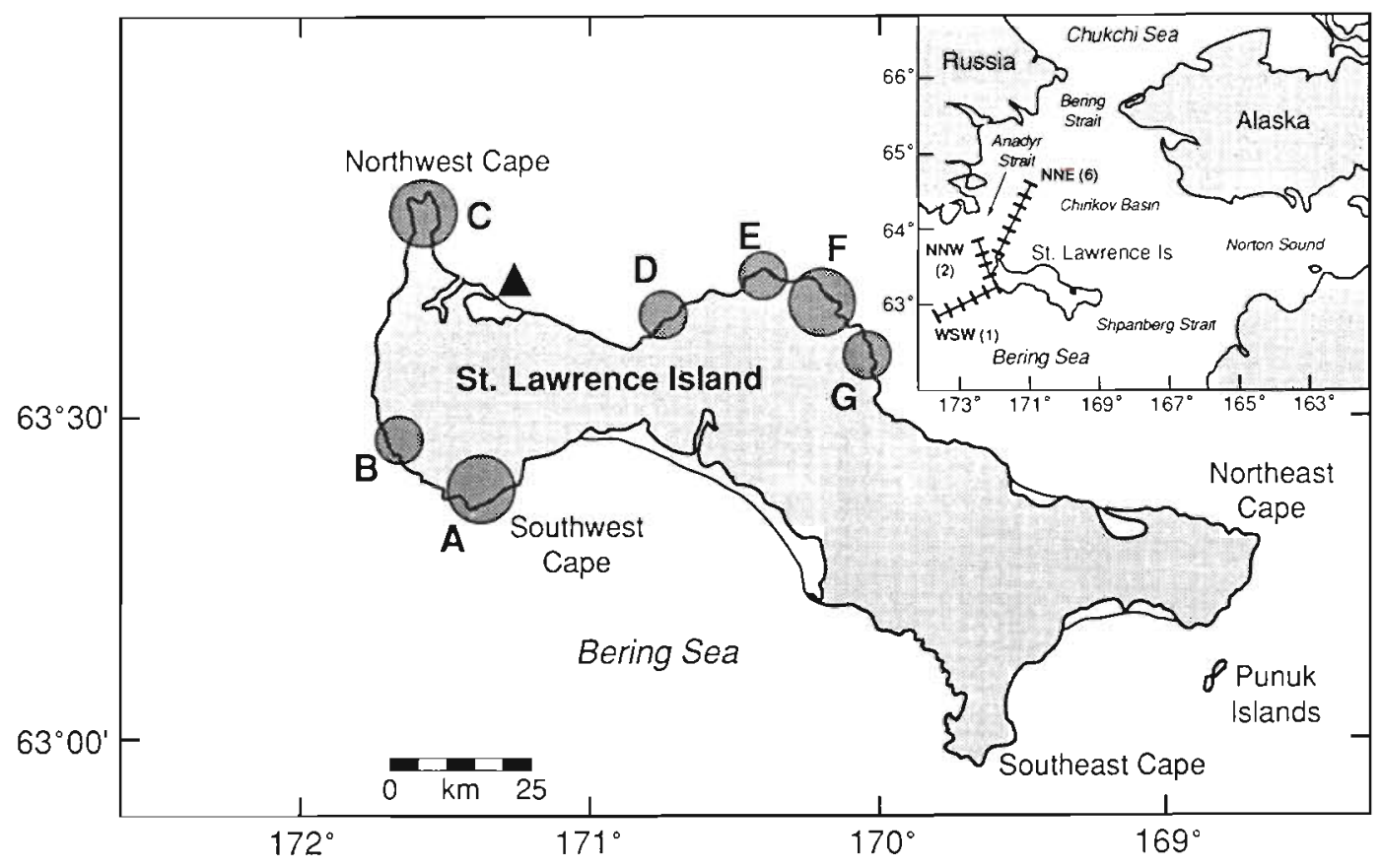

Fig. 1. Study area in the northwestern Bering Sea. Lettered circles refer to locations and relative sizes of major seabird colonies with alcids on the western side of St. Lawrence Island: $\mathrm{A}=$ Southwest Cape; $\mathrm{B}=\mathrm{Owalit}$ Mountain; $\mathrm{C}=$ Suvuokuk Mountain; $\mathrm{D}=$ Kaghkusalik; $\mathrm{E}=$ Savoonga $\mathrm{F}=$ Cape Myaughee $\mathrm{G}=$ Singikpo Cape. Small circles indicate total colony sizes of $10^{4}$ to $10^{5}$, large circles $10^{5}$ to $10^{6}$ (Estimates for alcid populations are given in Table 1 and Sowls et al. 1978). Triangle refers to the tidal reference station at the entrance to Niyrakpak Lagoon. Numbers (in parentheses) and directions of ship cruise tracks (WSW $=$ west-southwest, NNW = north-northwest, NNE = north-northeast) running away from St. Lawrence Island are illustrated within the inset. Hatch marks along cruise tracks denote positions of hydrographic stations (see Figs. 2,4 \& 7 )

bays, and bordering archipelagoes of the Bering Sea host 17 of the world's 22 extant alcids. Aethia auklets are endemic to North Pacific marginal seas. At least 8 alcids coexist in multispecies breeding colonies on western St. Lawrence Island (see Table 1). Small numbers of B. brevirostris, C. grylle, Synthliboramphus antiquus, and $A$. alle, all of which occur during spring and summer, suggest that additional species may breed locally.

Alcids have been well-studied on St. Lawrence Island. Early surveys of the island's avifauna (e.g. Fay \& Cade 1959) were later supplemented with detailed investigations of diet and nesting for many individual species (Sealy 1968, 1973, Bédard 1969b, c, Sealy \& Bédard 1973, Searing 1977, Roseneau et al. 1985, Piatt et al. 1988). During our study, colony attendance, population monitoring, and breeding biology of auklets were being studied concurrently at Kongkok Bay on the southwest coast of St. Lawrence Island (Piatt et al. 1990). In addition to these primarily terrestrial studies, several offshore surveys have examined aspects of the marine ecology of 1 or more species in Anadyr Strait, the Chirikov Basin, and other areas of the northern Bering Sea near several of the principal colonies (e.g. Hunt et al. 1990, Haney 1991, Schauer 1992).

\section{METHODS}

Methods for counting and identifying seabirds, surveying foraging zones used by alcids around St. Lawrence Island, and recording environmental variability along cruise tracks are described in Tasker et al. (1984) and Haney (1991). All data were collected between 18 August and 3 September 1987 (late chickrearing during most alcids' breeding cycle) along 3 cruise tracks repeated in Anadyr Strait (Fig. 1) aboard the USFWS MV 'Eagle-Tiglax'. Alcids sitting on the ocean surface were counted at sea by paired observers during 260 timed counts of 10 min duration corresponding to band transects of width $300 \mathrm{~m}$ and length approximately $3 \mathrm{~km}$. Counts of sitting birds likely included both non-breeders and breeders commuting from nearby colonies. Common (Uria aalge) and thick-billed murres ( $U$. lomvia) could not be regularly differentiated during censusing, so we combined them into 1 taxonomic grouping. Consequently, and due to the rarity of 4 alcids in the study area $(\leq 4$ individuals recorded offshore; Table 1), species abundances for 7 alcid taxa were available for analysis: horned puffin Fratercula corniculata (HOPU); tufted puffin F. cirrhata (TUPU); parakeet auklet Aethia psittacula (PAAU); least auklet $A$. pusilla 
(LEAU); crested auklet A. cristatella (CRAU); pigeon guillemot C. columba (PIGU); common and thick-billed murres (MURR). Abundances of each alcid taxon were transformed by applying $\sqrt{x}+\sqrt{x+1}$ on the counts for each transect prior to computing a correlation matrix. This procedure stabilizes variances of enumerated data (Snedecor \& Cochran 1980, p. 288), and smoothes some of the noise resulting from variables measured on different scales (see below).

Twenty-two environmental variables were measured for, or assigned to, each transect. One variable described the sequential or Julian date (JLDT) and another the minimum distance from land in kilometers (DIST) for each transect. Sixteen variables described aspects of the physical structure in the marine environment. Sed surface iemperdture (SST) and salinity (SSS) at transect midpoints, as well as corresponding gradients ( $\triangle S S T$ and $\triangle S S S$ ) computed from maximum differences between transect start- and endpoints, were recorded to the nearest tenth of a ${ }^{\circ} \mathrm{C}$ and part per thousand (ppt), respectively, with a continuously running thermosalinograph. Tidal stage was measured as a percentage of full ebb (EBTD) or full flood (FLTD) according to corrections in tidal tables for the entrance to Niyrakpak Lagoon, St. Lawrence Island (Fig. 1), referenced to times and heights of tides at Nushagak Bay (Clarks Point), Alaska (A.E.I.D.C., Univ. of Alaska, Anchorage). Values for FLTD and EBTD were assigned 'zero' values during opposing tidal stages. Tidal range (TDRG) on the date and time each transect was surveyed was given to the nearest centimeter. Six variables described elements of the subsurface habitats in which alcids forage (see Fig. 2 in Haney 1991, p. 422, for details). Depth (PYDE) and thickness of the pycnocline (PYTH), upper-mixed layer depth (UMDE), lower-mixed layer depth (LMDE). and total water column depth (TODE) were sampled or interpolated to the nearest tenth of a meter. Pycnocline strength (PYST) was measured in $\sigma_{t}$ units per vertical meter. Every few hours, or when weather changed during the surveys, barometric pressure (BARO) measured to the nearest hundredth of an inch of mercury, windspeed in knots (WDSP), and swell height in feet (SWHT) were recorded from data kept in the ship's bridge log.

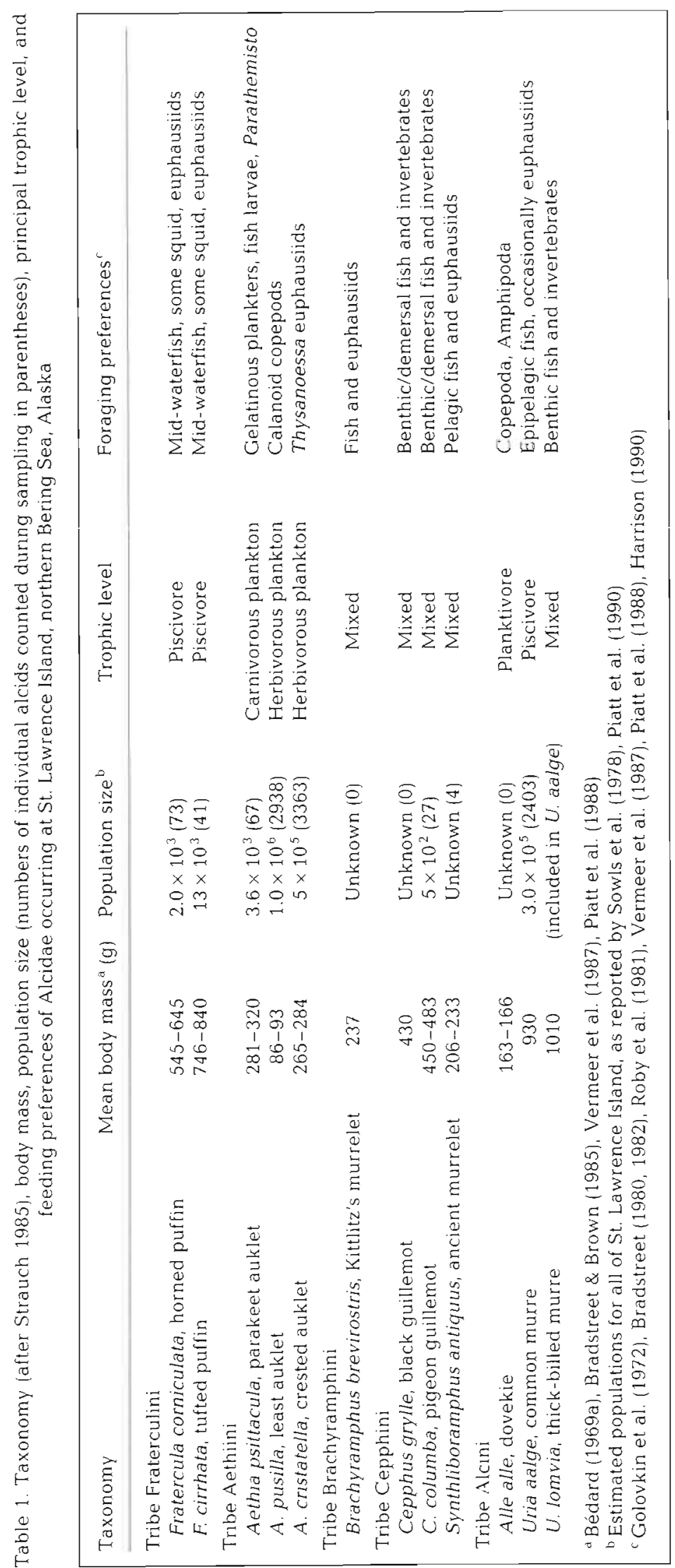


Zooplankton were sampled at 52 hydrographic stations along the cruise tracks with a 1 m diameter ring net, or N1O net. Occasional high winds prevented tows at 8 additional stations. We towed the ring net vertically at a constant speed of $15 \mathrm{~m} \mathrm{~min}^{-1}$ from as near the bottom of the water column as conditions allowed. Therefore, each station sample represented an integrated view of zooplankton abundance over a known depth. A 'Sameoto net', or otter surface sampler, was also deployed from 58 stations to collect neuston samples (Sameoto \& Jaroszynski 1969). These tows were made for $10 \mathrm{~min}$ along the cruise track starting as close as possible to the original station position. For each sample, we recorded beginning and ending position, deployment time, time not sampling (when the net mouth bounced above the sea surface), and tow velocity. We towed the Sameoto net at a constant speed throughout the sampling interval, approximately 3 knots in each case.

Zooplankton from both nets were preserved in formalin diluted to $5 \%$ strength in seawater and then sorted and identified later at the University of AlaskaFairbanks. Zooplankters were identified to the highest taxonomic level possible, usually to species (Table 2). Large or non-abundant animals numbering approximately 100 sample $^{-1}$ were counted individually (e.g. Sagitta elegans, Neocalanus cristatus). The numbers of small and more numerous animals were estimated by counting all zooplankters in a $5 \mathrm{ml}$ subsample and extrapolating to the total sample volume

Table 2. Zooplankton taxa and species collected in vertical tows from the Bering Sea around St. Lawrence Island, Alaska, 20 August to 1 September 1987 (taxonomy follows Motoda \& Minoda 1974)

\begin{tabular}{|lc|}
\hline & Taxon/Species \\
\hline Hydrozoa & Euphausiacea \\
Coryne princeps & Thysannoessa spp. \\
Hydrozoa medusae & Decapoda \\
Trachylina & Anomura zoeae \\
Aglantha digitalis & Brachyura zoeae \\
Pteropoda & Chionoecetes sp. \\
Clione limacina & Hyppolytidae spp. \\
Limacina helicina & Oregoninae (megalopae) \\
Polychaeta & Pandalidae spp. \\
Autolytus sp. & Amphipoda \\
Chaetognatha & Hyperoche medusara \\
Eukrohnia hamata & Parathemisto libellula \\
Sagitta elegans & P.pacifica \\
Copepoda & Appendicularia \\
Calanus marshallae & Oikopleura spp. \\
Eucalanus bungii bungij & \\
Metridia lucens & \\
Neocalanus cristatus & \\
N. plumchrus & \\
Pseudocalanus minutus & \\
Scolecithricella minor & \\
\end{tabular}

Four biological variables were then employed to characterize this plankton community (Table 2). For each transect, the number of plankton species (PLDV), abundance of all plankton (PLAB), abundances of copepods, including known prey species (Calanus, Neocalanus, Eucalanus, Pseudocalanus, Scolecithricella and Metridia spp; (PAB), and abundances of euphausiids (Thysannoessa spp.; EUAB) were figured by taking the average of the 2 hydrographic stations (ca $17.8 \mathrm{~km}$ apart) adjacent to the transect after a $\sqrt{x}+\sqrt{x+1}$ transformation had been applied to the count values.

We then used all 260 transects as $0.3 \times 3.0 \mathrm{~km}$ 'sites' in a simultaneous, comparative evaluation of species' abundances and environmental variables. Several multivariate methods were considered initially. We chose principal components analysis (PCA) rather than factor analysis because of the indeterminate nature of factor scores in the latter technique (Wilkinson 1989, p. 79). We also considered canonical correlation, a technique that gave similar results to PCA for subsets of the same variables (unpubl. data). PCA, which allows data exploration without formal hypothesis testing, is often used to identify groups of covarying species alone (see Grossman et al. 1991 for examples). In our analysis, however, we summarized correlations among alcid species' abundances along with the environmental variables measured, a technique previously applied to freshwater fish and their habitats (Smith et al. 1981). Accordingly, we could examine species' interactions independent of, and in addition to, interactions with environmental variables describing potential resource dimensions,

Due to the vastly different measurement scales and data types, and because there was no basis for assuming that standard deviations on variables were theoretically significant (Wilkinson 1989, p. 76), the correlation (Appendix 1) rather than covariance matrix for the 22 environmental and 7 taxonomic variables was employed in the PCA. PCA summarizes trends in multivariate data sets with a minimum number of components, each of which groups items measuring (or associated with) some common dimension (Wilkinson 1989). Each sequential component is uniquely defined mathemetically, and orthogonal to others in the component space. Therefore, variances of each variable can be partitioned independently among the components, each of which accounts for the maximum portion of the remaining available total variance. We based a cut-off point for retaining components on the basis of their interpretability and explanation of a large amount of the original variance (90\%; Jolliffe 1986). This criterion differs from alternative criteria such as eigenvalues $>1$, or tests on eigenvalue equality in which the required assumptions (multivariate normality) may be difficult to meet (Grossman et al. 1991). 
To evaluate the stability in the components obtained with the complete data set, we reran the analysis with $50 \%$ of the cases $(n=130)$ deleted randomly.

We based interpretations for components on the 2nd to 5th largest component loadings (Table 3). Components were unrotated because rotated components using the VARIMAX option (Wilkinson 1989, p. 77) made little sense biologically. We characterized components as species interactions if the absolute value for the largest loadings originated from 2 or more taxonomic variables. In order to compare relative importances of resource dimensions to alcid abundances (collective association), means of all taxa's loadings were calculated for each component. Larger mean values indicated stronger collective relationships. For evaluating partitioning along each resource dimension, the mean for all pair-wise differences $(n=21$ ) in component loadings among taxa were computed for each component. A larger mean indicated greater relative pariitioniny among alcids along that resource dimension. Statistical analyses were run with SYSTAT (Wilkinson 1989).

\section{RESULTS}

The PCA resulted in 14 components (Table 3 ) which explained $90 \%$ of the original variance in the correlation matrix for the data. Ten of these components described resource or other environmental dimensions (Table 4), accounted for $75 \%$ of the original variance, and are listed first below.

The first component (PC1) grouped pycnocline depth, pycnocline thickness, upper- and lower-mixed layer depth, and sea surface temperature. All of these variables characterize warm, stratified conditions of the Bering Shelf Water mass (Coachman et al. 1975). This component also had high negative correlations with sea surface salinity and distance from land. Thìs, this com-

Table 3. Loadings of the 29 variables, including 7 alcid species or genera, on the first 14 principal components derived from the correlation matrix (Appendix 1). Bold-faced values were used for interpretating and characterizing the components. PYDE:

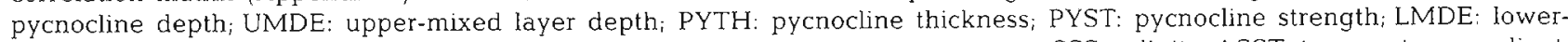
mixed layer depth; TODE: total water column depth; SST: sea surface temperature; SSS: salinity; $\Delta$ SST temperature gradient; $\triangle S S S$ : salinity gradient; EBTD: full ebb; FLTD: full flood; TDRG: tidal range; WDSP: windspeed; SWHT. swell height; BARO barometric pressure; DIST: distance from land; JLDT: Julian date; PLDV: no. of plankton species; PLAB: abundance of euphausiids; CPAB: abundance of copepods; MURR: common and thick-billed murres; HOPU: horned puffin; TUPU: tufted puffin; PIGU: pigeon guillemot; PAAU: parakeet auklet; CRAU: crested auklet; LEAU: least auklet

\begin{tabular}{|c|c|c|c|c|c|c|c|c|c|c|c|c|c|c|}
\hline Variable & 1 & 2 & 3 & 4 & 5 & 6 & 7 & 8 & 9 & 10 & 11 & 12 & 13 & 14 \\
\hline PYDE & 0.955 & 0.072 & -0.037 & 0.112 & -0.045 & 0.102 & -0.024 & 0.053 & -0.022 & -0.063 & 0.024 & 0.027 & 0.043 & 0.089 \\
\hline UMDE & 0.881 & 0.107 & -0.143 & 0.160 & -0.046 & 0.147 & 0.043 & 0.034 & 0.026 & -0.067 & 0.007 & -0.063 & -0.142 & 0.294 \\
\hline PYTH & 0.805 & -0.060 & 0.127 & -0.195 & -0.073 & -0.025 & -0.095 & -0.049 & -0.062 & -0.011 & -0.150 & 0.008 & 0.336 & -0.101 \\
\hline PYST & 0.681 & 0.364 & 0.261 & -0.092 & 0.058 & -0.007 & 0.043 & -0.035 & -0.048 & -0.045 & 0.104 & -0.074 & -0.364 & -0.219 \\
\hline LMDE & 0.782 & 0.382 & -0.316 & -0.052 & 0.081 & 0.030 & -0.095 & -0.118 & 0.077 & -0.100 & 0.143 & -0.014 & 0.048 & -0.014 \\
\hline TODE & 0.183 & 0.306 & -0.794 & 0.022 & 0.116 & 0.021 & -0.202 & -0.147 & 0.080 & -0.059 & 0.229 & 0.146 & 0.192 & 0.092 \\
\hline SST & 0.898 & 0.087 & 0.190 & -0.195 & -0.045 & -0.116 & -0.018 & 0.092 & -0.042 & -0.006 & 0.092 & -0.024 & 0.028 & -0.012 \\
\hline SSS & -0.603 & 0.091 & -0.148 & 0.544 & 0.049 & 0.321 & 0.091 & 0.029 & -0.004 & 0.062 & 0.088 & -0.031 & -0.069 & 0.204 \\
\hline$\Delta \mathrm{SST}$ & -0.339 & -0.156 & 0.110 & -0.249 & -0.037 & -0.500 & -0.117 & 0.228 & 0.051 & -0.047 & 0.565 & -0.037 & -0.162 & 0.232 \\
\hline$\Delta S S S$ & -0.018 & -0.198 & 0.282 & 0.594 & -0.142 & -0.441 & -0.232 & -0.101 & 0.182 & -0.026 & 0.007 & 0.014 & 0.201 & 0.083 \\
\hline EBTD & -0.031 & 0.036 & 0.296 & 0.310 & -0.676 & 0.181 & -0.167 & -0.150 & 0.330 & 0.002 & 0.017 & -0.119 & 0.002 & 0.125 \\
\hline FLTD & 0.066 & -0.118 & -0.187 & -0.322 & 0.693 & -0.093 & 0.219 & -0.046 & -0.372 & 0.011 & 0.026 & 0.048 & 0.005 & 0.170 \\
\hline TDRG & 0.066 & 0.588 & -0.263 & -0.137 & 0.295 & 0.077 & 0.380 & -0.028 & 0.488 & 0.080 & 0.063 & 0.024 & 0.004 & -0.007 \\
\hline WDSP & -0.082 & 0.169 & 0.331 & 0.701 & 0.157 & -0.015 & -0.138 & 0.221 & -0.091 & -0.028 & 0.267 & 0.232 & 0.089 & -0.260 \\
\hline SWHT & 0.045 & 0.394 & 0.343 & 0.586 & 0.210 & -0.243 & -0.057 & -0.091 & -0.222 & -0.081 & 0.197 & -0.123 & 0.215 & -0.086 \\
\hline BARO & -0.027 & -0.778 & -0.394 & 0.100 & -0.134 & 0.009 & -0.324 & -0.012 & -0.014 & -0.004 & 0.025 & 0.180 & -0.029 & -0.036 \\
\hline DIST & -0.609 & 0.488 & -0.120 & 0.009 & 0.257 & -0.176 & -0.003 & -0.334 & 0.185 & 0.031 & -0.006 & 0.192 & 0.122 & 0.017 \\
\hline JLDT & -0.111 & 0.451 & 0.645 & -0.255 & 0.157 & -0.091 & 0.176 & 0.195 & 0.178 & 0.032 & -0.113 & 0.033 & -0.006 & 0.030 \\
\hline PLDV & -0.500 & 0.542 & 0.197 & -0.372 & -0.121 & 0.006 & -0.068 & -0.141 & -0.315 & -0.005 & -0.085 & -0.001 & -0.083 & 0.043 \\
\hline PLAB & -0.333 & 0.388 & -0.138 & -0.464 & -0.434 & 0.182 & -0.093 & 0.293 & -0.089 & -0.144 & 0.148 & -0.013 & 0.132 & -0.061 \\
\hline EUAB & 0.062 & 0.534 & 0.476 & 0.190 & -0.262 & 0.030 & -0.227 & -0.286 & -0.138 & -0.055 & -0.056 & 0.205 & -0.006 & 0.285 \\
\hline CPAB & -0.209 & 0.405 & -0.232 & -0.372 & -0.330 & 0.458 & 0.067 & 0.359 & -0.121 & -0.119 & 0.129 & 0.104 & 0.064 & -0.073 \\
\hline MURR & -0.045 & -0.236 & 0.373 & -0.334 & 0.315 & 0.375 & -0.253 & -0.151 & 0.194 & -0.091 & 0.045 & 0.428 & -0.131 & -0.133 \\
\hline HOPU & 0.118 & -0.363 & 0.168 & -0.074 & -0.317 & 0.044 & 0.473 & -0.352 & 0.110 & 0.199 & 0.376 & -0.054 & 0.057 & -0.174 \\
\hline TUPU & 0.157 & -0.349 & 0.299 & -0.092 & -0.243 & 0.233 & 0.526 & -0.178 & -0.263 & $-0,018$ & 0.146 & 0.294 & 0.110 & 0.169 \\
\hline PIGU & 0.072 & -0.261 & 0.166 & 0.281 & 0.059 & -0.208 & 0.322 & 0.329 & 0.233 & -0.578 & -0.136 & 0.193 & 0.064 & 0.100 \\
\hline PAAU & 0.249 & -0.042 & 0.274 & 0.049 & 0.193 & 0.134 & -0.098 & 0.429 & 0.089 & 0.670 & 0.003 & 0.108 & 0.161 & 0.157 \\
\hline CRAU & 0.162 & -0.212 & 0.363 & -0.168 & 0.492 & 0.434 & -0.338 & -0.080 & 0.083 & -0.131 & 0.181 & -0.136 & -0.063 & 0.082 \\
\hline LEAU & -0.398 & -0.246 & 0.296 & -0.101 & 0.350 & 0.416 & 0.012 & -0.042 & 0.042 & -0.226 & 0.068 & -0.389 & 0.269 & 0.050 \\
\hline
\end{tabular}


Table 4. Interpretations for the first 14 principal components describing alcid species associations and environmental variability at sea near St. Lawrence Island, Alaska. Eigenvalue, percentage variation, and cumulative variation explained by components are listed in parentheses

\begin{tabular}{|c|c|c|}
\hline Principal component & Interpretation & Designated name \\
\hline Component $1(5.833 ; 20 \% ; 20 \%)$ & $\begin{array}{l}\text { Contrasts the Bering Shelf water mass, with its strati- } \\
\text { fied water column and higher surface temperatures, } \\
\text { with other water types }\end{array}$ & Core Bering Shelf Water \\
\hline Component $2(3.441 ; 12 \% ; 32 \%)$ & $\begin{array}{l}\text { Contrasts temporal coincidence of high tidal range, } \\
\text { storms, and greater plankton diversity and } \\
\text { euphausiid abundance with other conditions }\end{array}$ & Temporal trends \\
\hline Component $3(2.907 ; 10 \% ; 42 \%)$ & $\begin{array}{l}\text { Contrasts shallow (but not necessarily nearshore) } \\
\text { continental shelf depths and higher euphausiid } \\
\text { abundances sampled later during the study period } \\
\text { with other conditions }\end{array}$ & Time-area interaction \\
\hline Component $4(2.737 ; 9 \% ; 51 \%)$ & $\begin{array}{l}\text { Contrasts tendency for higher, more uniform surface } \\
\text { salinities, higher swell heights, and lower plankton } \\
\text { abundances to occur during high wind speeds }\end{array}$ & Sea surface conditions \\
\hline Component $5(2.304 ; 8 \% ; 59 \%)$ & $\begin{array}{l}\text { Contrasts interaction between abundances of } \\
\text { plankters caught and tidal stage }\end{array}$ & Tidal stage \\
\hline Component $6(1.603 ; 6 \% ; 65 \%)$ & $\begin{array}{l}\text { Contrasts high copepod abundances caught in } \\
\text { areas of high salinity away from water mass edges }\end{array}$ & Core Anadyr Water \\
\hline Component $7(1.380 ; 5 \% ; 70 \%)$ & $\begin{array}{l}\text { Contrasts co-associations of horned and tufted } \\
\text { puffins, and tendency for neither to occur with } \\
\text { crested auklet }\end{array}$ & Species interaction 1 \\
\hline Component $8(1.141 ; 4 \% ; 74 \%)$ & $\begin{array}{l}\text { Contrasts co-association of pigeon guillemot and } \\
\text { parakeet auklet, and tendency for neither to occur } \\
\text { with horned puffin }\end{array}$ & Species interaction 2 \\
\hline Component $9(0.997 ; 3 \% ; 77 \%)$ & $\begin{array}{l}\text { Contrasts low plankton diversity sampled during } \\
\text { ebb tides coinciding with periods of high tidal range }\end{array}$ & Tidal range-stage interaction \\
\hline Component $10(0.984 ; 3 \% ; 80 \%)$ & $\begin{array}{l}\text { Contrasts tendency of neither pigeon guillemot nor } \\
\text { least auklet to occur with parakeet auklet }\end{array}$ & Species interaction 3 \\
\hline Component $11(0.841 ; 3 \% ; 83 \%)$ & $\begin{array}{l}\text { Contrasts shoaling, compaction, or movements of } \\
\text { sea surface isotherms during periods of high winds } \\
\text { with other conditions }\end{array}$ & Air-sea interaction \\
\hline Component $12(0.736 ; 3 \% ; 86 \%)$ & $\begin{array}{l}\text { Contrasts co-association of murres and tufted puffin, } \\
\text { and tendency for neither to occur with least auklet }\end{array}$ & Species interaction 4 \\
\hline Component $13(0.616 ; 2 \% ; 88 \%)$ & $\begin{array}{l}\text { Contrasts correspondence between a weak and } \\
\text { thick pycnocline }\end{array}$ & Pycnocline \\
\hline Component $14(0.599 ; 2 \% ; 90 \%)$ & $\begin{array}{l}\text { Contrasts abundant euphausiids caught at locations } \\
\text { with surface temperature gradients, a thick upper- } \\
\text { mixed layer, and weak pycnocline }\end{array}$ & Coastal Water \\
\hline
\end{tabular}

ponent contrasted a dimension of the macro-habitat used by foraging alcids, with Bering Shelf Water (Fig. 2) occupying one end of the gradient. The second component (PC2) contrasted a temporal or intra-seasonal trend: high tidal range, high plankton diversity and euphausiid abundance, and low barometric pressure associated with storms occurring late in the survey period versus opposite conditions earlier (cf. Fig. 3). The third component (PC3) described mainly a trend from sampling shallow areas late during the study period with opposite conditions earlier (Fig. 3). Low component loadings on DIST (Table 3) resulted because some shallow areas (i.e. offshore banks) were located offshore. The fourth component (PC4) described a contrast in the micro-habitat of the ocean surface, i.e. a gradient running from high, uniform sea surface salinities, higher swell heights, and low plankton abundances during high winds to opposite conditions during calm weather. The fifth component (PC5) described a gradient in plankton abundance associated with tidal stage (high abundance during ebbs versus low abundance during floods; Tables $3 \& 4$ ).

Component 6 (PC6) grouped greater copepod abundances with waters of high, uniform salinity. This component thus contrasted a second gradient in macrohabitat between core Anadyr Water and other water mass types (Figs. 2 \& 4). The ninth component (PC9) described an interactive gradient contrasting low plankton diversity during low-amplitude flood tides 
Stations
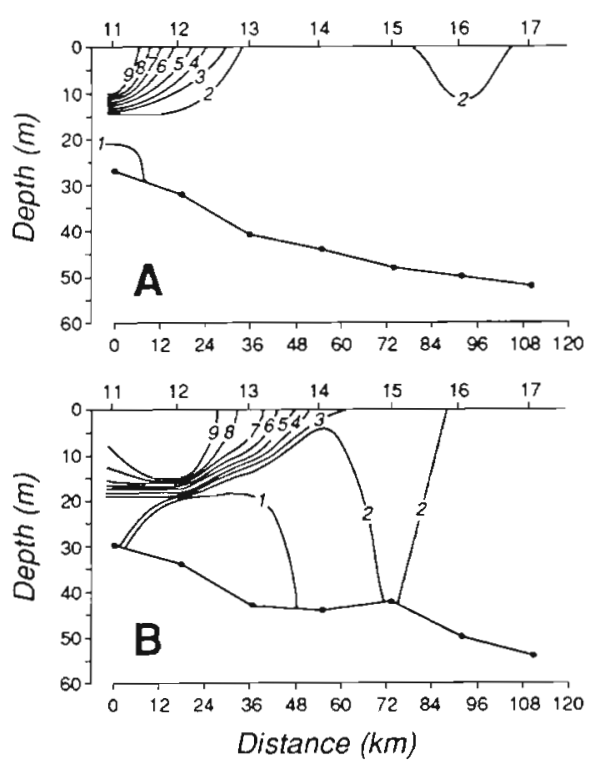

Stations
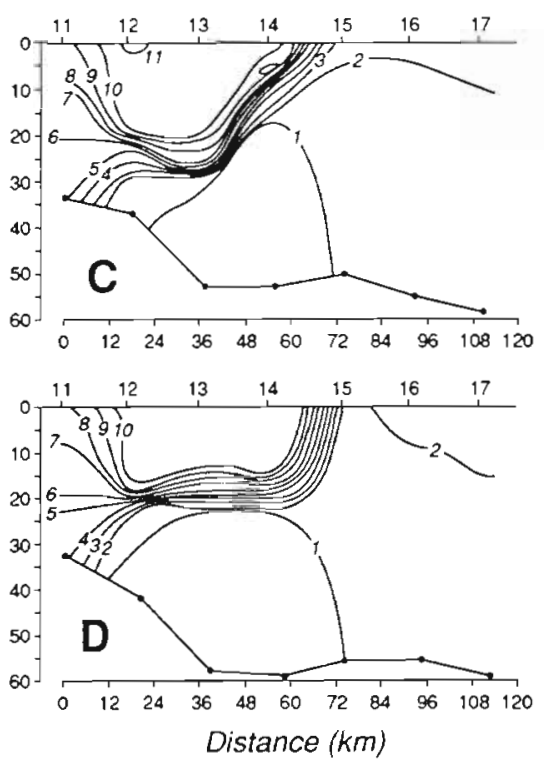

Stations
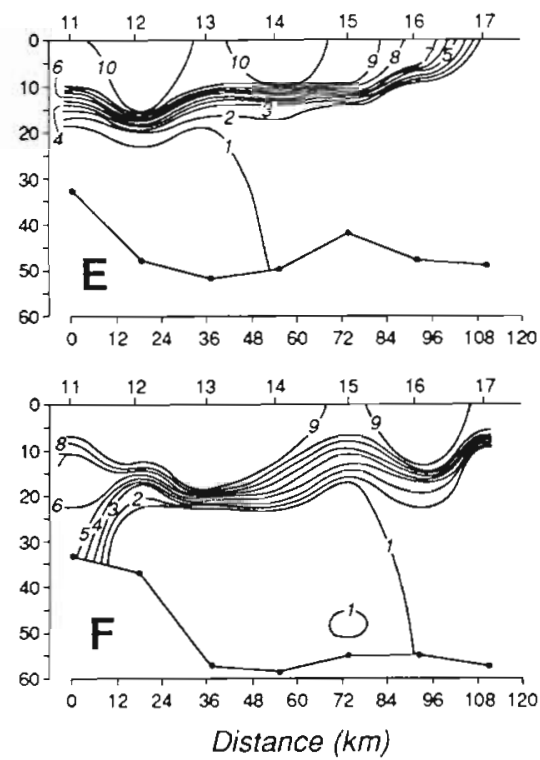

Temperature $\left({ }^{\circ} \mathrm{C}\right)$

Fig. 2. Temperature sections on 6 different days along the north-northeast cruise tracks (see also Fig. 1). Survey dates: $A=23$ August; $B=24$ August $; C=28$ August $D=29$ August; $E=31$ August $F=1$ September 1987 . Note the 3 water mass types: cold, mixed Anadyr Water at the extreme right; strongly stratified Bering Shelf Water in the middle; and weakly stratified Coastal Water at the extreme left of the figure panels

with high plankton diversity during high-amplitude ebb tides. Component 11 (PC11) described a constrast in an air-sea interaction, i.e. shoaling, compaction, or movement of sea surface isotherms during high winds at one end of the gradient versus opposite conditions at the other (Fig. 2). The thirteenth component (PC13) contrasted a correspondence between swells and a weak/thick pycnocline versus opposite conditions. And finally, Component 14 (PC14) grouped high euphausiid abundance, sea surface temperature differences, a thick upper-mixed layer, and weak pycnocline with opposite conditions. This component thus described a third gradient in macro-habitat with a Coastal Water mass (Figs. $2 \& 4$ ) at one end of the axis.

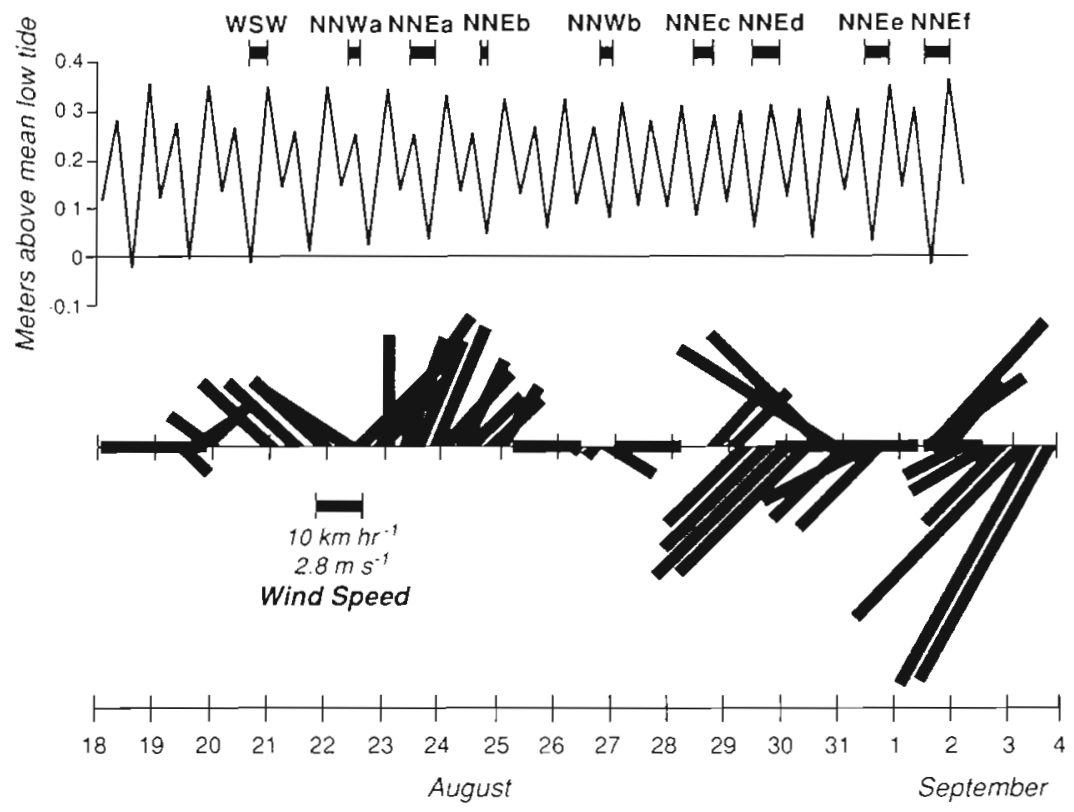

Fig. 3. Ship-board data collection in relation to temporal variability in tidal regime, wind speed, and wind direction in Anadyr Strait, northwestern Bering Sea, Alaska. Time periods of ship surveys during August and September 1987 are given along the top of the illustration at the same temporal scale as changes in tides and winds below. WSW, NNW, and NNE indicate direction of cruise tracks as in Fig. 1 


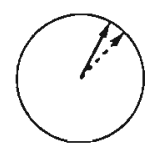

Stations
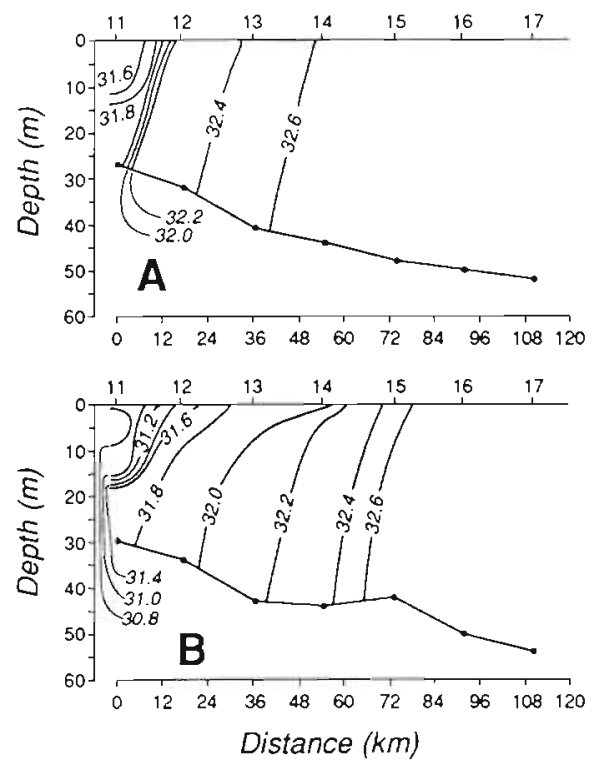

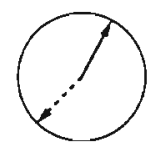

Stations
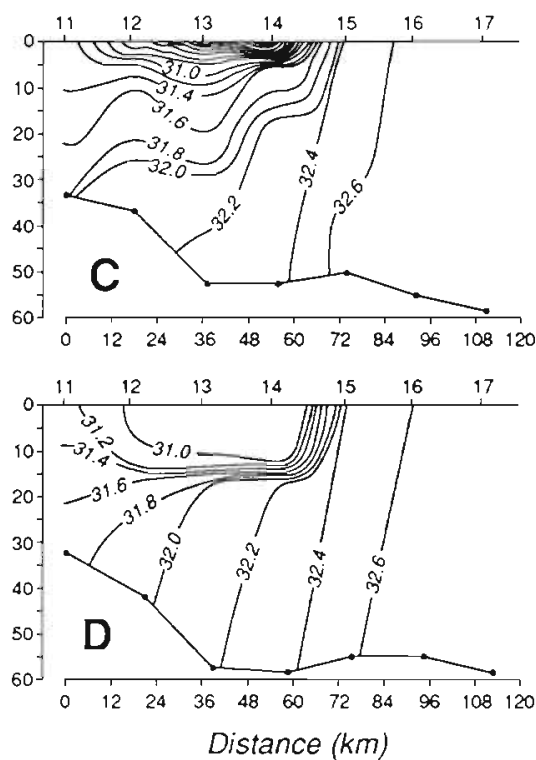

Salinity (ppt)

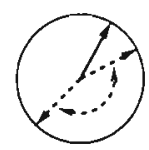

Stations
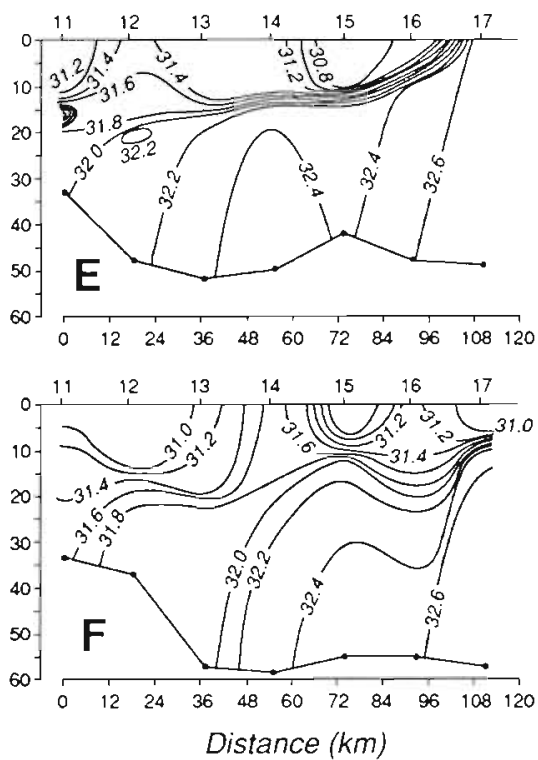

Fig. 4. Salinity (ppt) sections on 6 different days during August and September 1987 along the north-northeast cruise tracks (see also Fig. 1). Survey dates as in Fig. 2. Note 3 major differences in the macro- (water mass location, extent) and micro-habitat (sea surface isotherms, subsurface structure) used by alcids during periods of contrasting wind forcing [wind direction ( $-\rightarrow$ ) relative to cruise track $(\longrightarrow$ ) is illustrated in circles above figure panels]. (A) and (B) illustrate southwesterly winds resulting in retention of Bering Shelf Water nearshore, little horizontal stratification, and more Anadyr Water intruding from further offshore. (C) and (D) illustrate strong stratification, more Bering Shelf, and less Anadyr Water just after a 4 d period of calm winds. (E) and (F) show mixed conditions of stratification and multiple shoaling of the pycnocline or eddies during a period of wind reversals (cf. Fig. 3)

Four remaining components (PCs $7,8,10$ \& 12) described primarily interactions between or among alcid taxa, and accounted collectively for $15 \%$ of the original variance. The seventh component (PC7) contrasted co-associations of the 2 puffin species, and the tendency of both to be negatively associated with crested auklets. Component 8 (PC8) described a coassociation between pigeon guillemots and parakeet auklets, with neither occurring with horned puffin. The tenth component ( $\mathrm{PC} 10)$ contrasted a strong negative association of pigeon guillemot (and to a lesser extent least auklet) with parakeet auklet. Component 12 ( $\mathrm{PC} 12)$ described a negative association of both murres and tufted puffins with least auklets.

Components having the highest correlations with alcid abundances were tidal stage, the time-area interaction, the Anadyr Water mass, the temporal trend, and Bering Shelf Water (Table 5). Greatest variability in the PC loading values among alcids occurred on the axis of tidal stage. Anadyr Water, Bering Shelf Water, sea-surface conditions, and an air-sea interaction also suggested partitioning within the alcid community in Anadyr Strait (Table 5).

Species pairs exhibiting similar associations along 1 or a few axes segregated on others. For example, alcids partitioned macro-habitat defined by water mass type (Fig. 5). With their strong positive affinity for Anadyr Water and generally strong negative affinity for Bering Shelf Water, least auklets were the most specialized in their use of macro-habitat. This small-bodied, probably weak-diving species was also the most strongly associated with gradients in the pycnocline (Table 5 ; see also Haney 1991). Most other alcids occupied similar portions of the niche space, but the 2 puffins and pigeon guillemot also segregated from other alcids along axes defining the water masses. No alcids occupied macrohabitat defined by warm saline and cold stratified water (lower corner of Fig. 5), habitats which do not normally occur in this portion of the northern Bering Sea.

Several species-pairs exhibited segregation. Horned and tufted puffins displayed similar affinities (strength and direction of component correlations) for tidal 


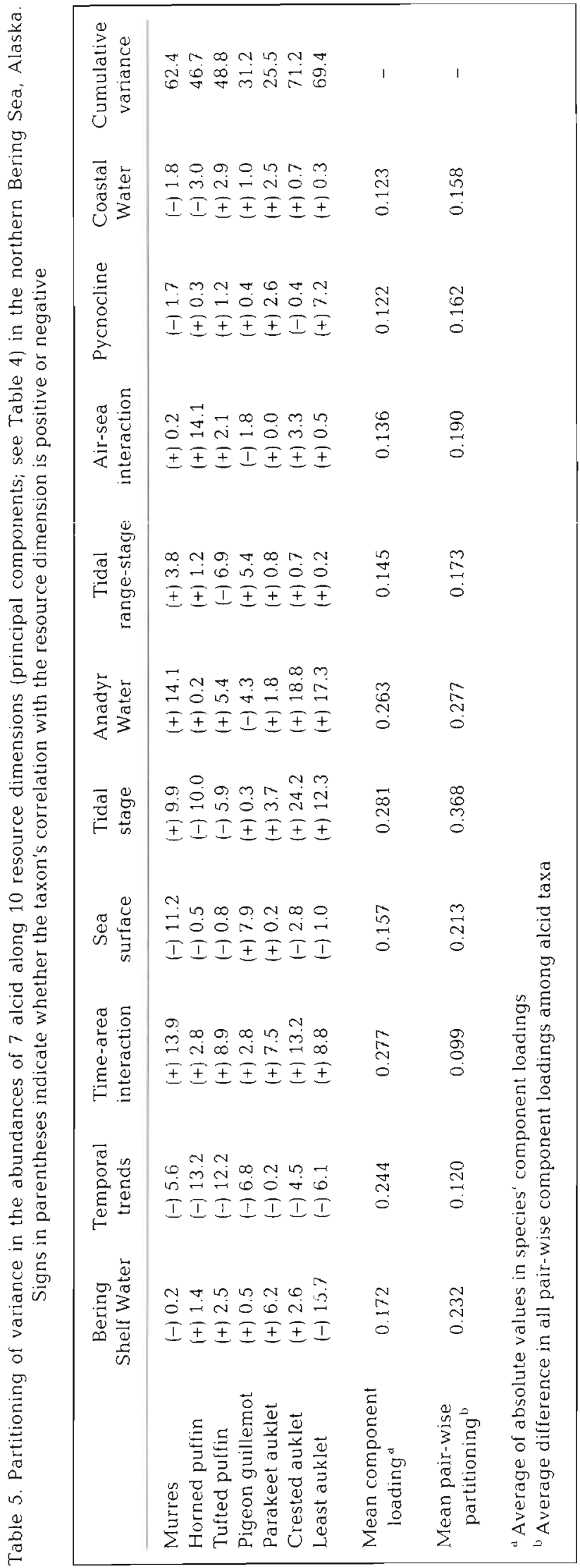

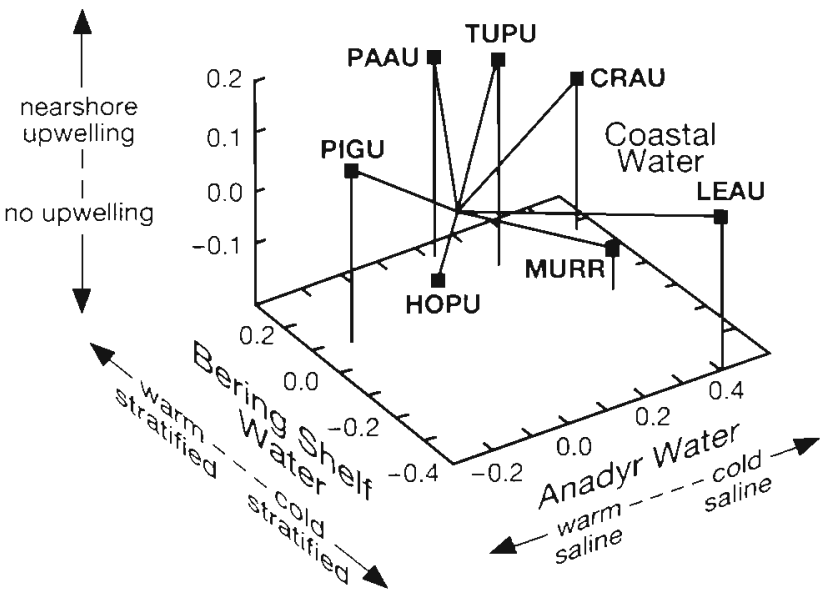

Fig. 5. Ordination (vectors of PCA factor loadings) of 7 alcid taxa along axes of macro-habitat (water mass type). HOPU = horned puffin, TUPU = tufted puffin, PAAU = parakeet auklet, LEAU = least auklet, $\mathrm{CRAU}=$ crested auklet, $\mathrm{PIGU}=$ pigeon guillemot, MURR = common and thick-billed murre. Relative distances among species indicate degree of partitioning along 3 resource dimensions

stage, Bering Shelf Water, and sea surface conditions, but they segregated markedly along gradients related to Coastal Water and the interaction between tidal range and tidal stage (Fig. 6). Similarly, parakeet and crested auklets showed dissimilar strength of association with Anadyr Water, and in their direction of response to the air-sea interaction and micro-habitat of the sea surface (Table 5).

Subsampling indicated that component axes were stable. Table 6 shows eigenvalues, proportion of original variance explained, and factor loadings for the first principal component for both the complete data set and a randomly selected $50 \%$ subsample. Factor load-

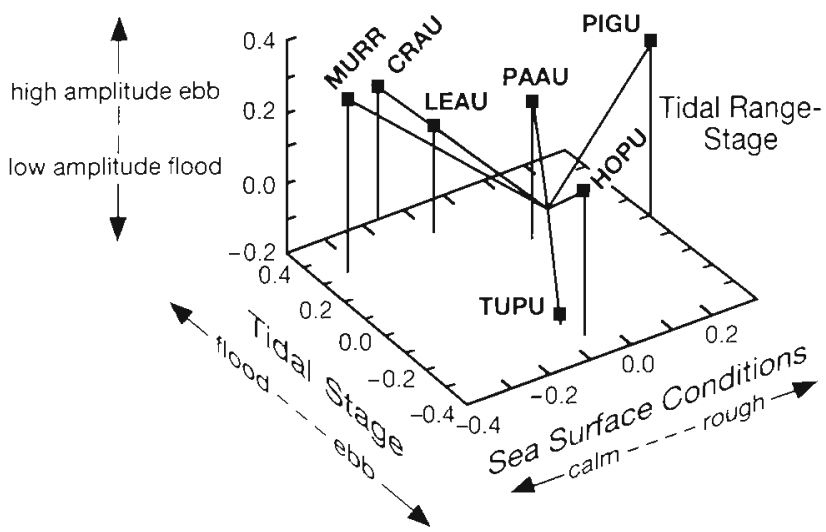

Fig. 6. Ordination (vectors of PCA factor loadings) of 7 alcid taxa along axes of tidal stage, a tidal range-stage interaction, and sea surface conditions. Relative distances among species indicate degree of partitioning along 3 resource dimensions. Taxonomic abbreviations as in Fig. 5 
Table 6. Comparative stability of principal components. Shown are eigenvalues, proportion of variance explained and all variable factor loadings for PC1 derived from the complete data set $(n=260$ cases) and a $50 \%$ random subsample ( $n=130$ cases). See Table 3 for abbreviations

\begin{tabular}{|c|c|c|c|c|c|c|c|}
\hline & \multicolumn{2}{|c|}{$\begin{array}{c}\text { Eigenvalue } \\
\text { Complete set Subsample }\end{array}$} & \multicolumn{2}{|c|}{$\begin{array}{c}\text { Proportion of variance explained } \\
\text { Complete set Subsample }\end{array}$} & & \multicolumn{2}{|c|}{$\begin{array}{l}\text { Factor loadings on PC1 } \\
\text { Complete set Subsample }\end{array}$} \\
\hline PC1. & 5.833 & 5.857 & 0.201 & 0.202 & PYDE: & 0.955 & 0.956 \\
\hline PC2: & 3.441 & 3.383 & 0.119 & 0.117 & UMDE: & 0.881 & 0.899 \\
\hline PC3: & 2.907 & 3.099 & 0.100 & 0.107 & PYTH: & 0.805 & 0.797 \\
\hline PC4: & 2.737 & 2.895 & 0.094 & 0.100 & PYST: & 0.681 & 0.670 \\
\hline PC5: & 2.304 & 2.103 & 0.079 & 0.073 & LMDE: & 0.782 & 0.799 \\
\hline PC6: & 1.603 & 1.747 & 0.055 & 0.060 & TODE: & 0.183 & 0.205 \\
\hline PC7: & 1.380 & 1.343 & 0.048 & 0.046 & SST. & 0.898 & 0.870 \\
\hline PC8: & 1.141 & 1.198 & 0.039 & 0.041 & SSS: & -0.603 & -0.496 \\
\hline PC9: & 0.997 & 1.132 & 0.034 & 0.039 & DSST: & -0.339 & -0.335 \\
\hline PC10: & 0.984 & 0.895 & 0.034 & 0.031 & DSSS: & -0.018 & -0.131 \\
\hline PC11. & 0.841 & 0.790 & 0.029 & 0.027 & EBTD: & -0.031 & 0.173 \\
\hline PC12: & 0.736 & 0.732 & 0.025 & 0.025 & FLTD: & 0.066 & -0.064 \\
\hline PC13: & 0.616 & 0.638 & 0.021 & 0.022 & TDRG: & 0.066 & 0.012 \\
\hline PC14: & 0.599 & 0.609 & 0.021 & 0.021 & WDSP: & -0.082 & -0.029 \\
\hline & & & & & SWHT: & 0.045 & 0.079 \\
\hline & & & & & BARO: & -0.027 & 0.007 \\
\hline & & & & & DIST: & -0.609 & -0.634 \\
\hline & & & & & JLDT: & -0.111 & -0.214 \\
\hline & & & & & PLDV: & -0.500 & -0.524 \\
\hline & & & & & PLAB: & -0.333 & -0.263 \\
\hline & & & & & EUAB: & 0.062 & 0.097 \\
\hline & & & & & CPAB: & -0.209 & -0.125 \\
\hline & & & & & MURR: & -0.045 & -0.077 \\
\hline & & & & & HOPU: & 0.118 & 0.194 \\
\hline & & & & & TUPU: & 0.157 & 0.214 \\
\hline & & & & & PIGU: & 0.072 & 0.102 \\
\hline & & & & & PAAU: & 0.249 & 0.195 \\
\hline & & & & & CRAU: & 0.162 & 0.100 \\
\hline & & & & & LEAU: & -0.398 & -0.482 \\
\hline
\end{tabular}

ings on Components 1 to 7 from the random subsample were also similar to those in the complete data set: Components $3 \& 4$ in the subsample were ordered in reverse, however (unpubl. data).

\section{DISCUSSION}

In reducing 22 original to 10 compound variables, PCA successfully identified redundancy among environmental descriptors and generally produced interpretable gradients in resource dimensions for the alcid community. The PCA correctly identified attributes of northern Bering Sea water masses (e.g. high copepod abundance in Anadyr Water), oceanographic processes such as nearshore upwelling and euphausiid concentrations (cf. Bédard 1969b), alterations of the sea surface associated with synoptic weather systems (PC4 in Table 4), and changes in macro- and micro-habitat (Figs. 2, 4 \& 7) arising from meso-scale wind forcing and advection (cf. Table 5; Fig. 3). Component 3, however, consisted of a time-area relationship (Table 4), probably a consequence of our inability to allocate equally sampling effort across all environmental conditions during the study period (see top half of Fig. 3). A common occurrence in field studies (see Eberhard \& Thomas 1991), this sampling problem especially confounds marine investigations where seabird mobility and short-term change in environmental conditions plague survey designs (Haney \& Solow 1992). High correlations of species abundances with what is essentially a sampling artifact (Tables 3 \& 4) argue for caution when attempting to interpret field studies of biological communities based on limited measurements along only a few (e.g. 1 to 3 ) resource dimensions.

We detected partitioning among alcids within several but not all resource dimensions identified with the PCA. Some dimensions had high correlations with alcid abundances, but gave no evidence for partitioning (e.g. abundances of all species were positively correlated with the temporal or intra-seasonal trend in tidal range, storms, and plankton diversity; PC2 in Table 4). Measured by interspecific differences along any single axis, tidal stage (ebb versus flood) gave the greatest degree of partitioning among the alcid taxa (Table 5). Alcid abundances have been related to tidal 

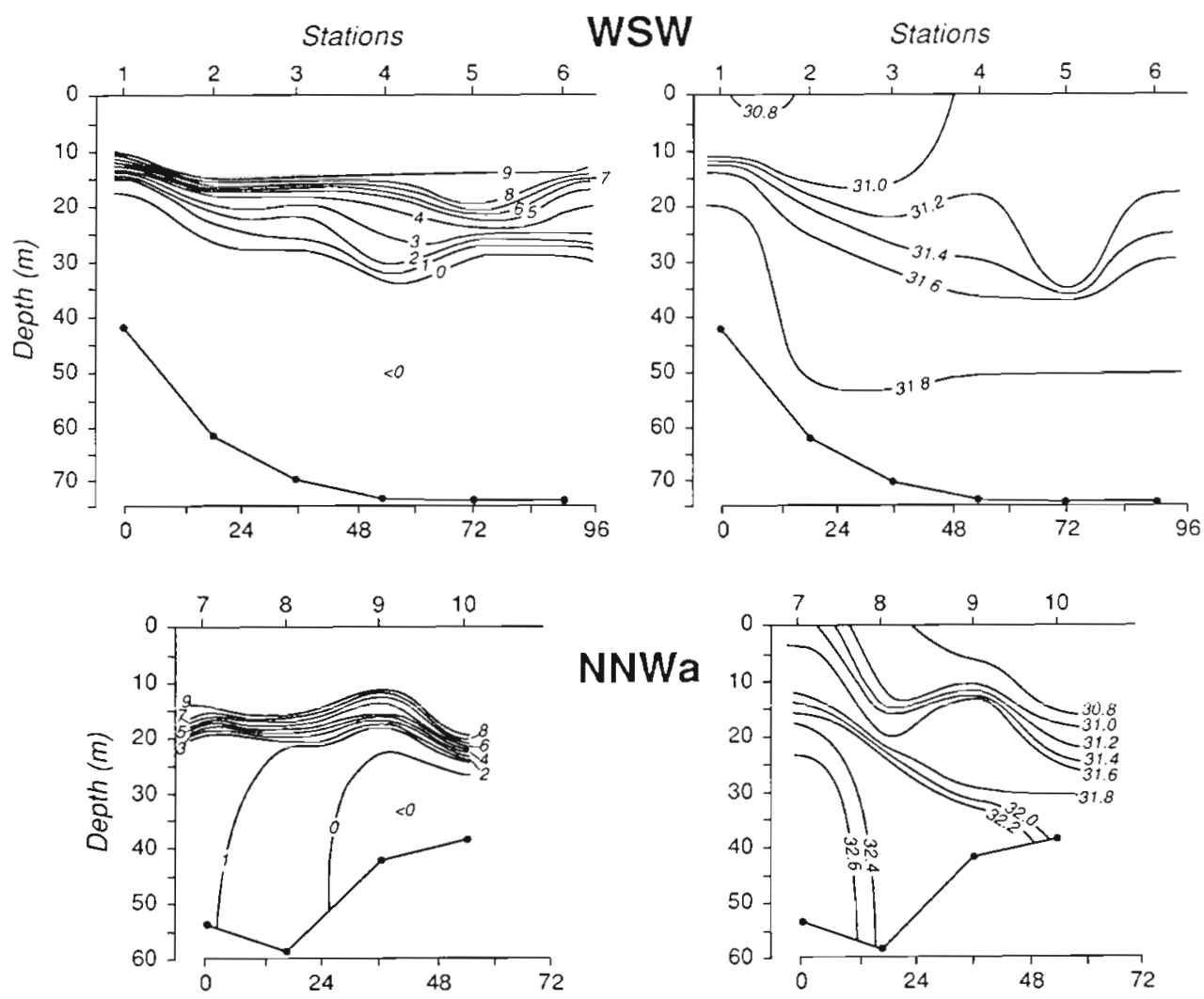

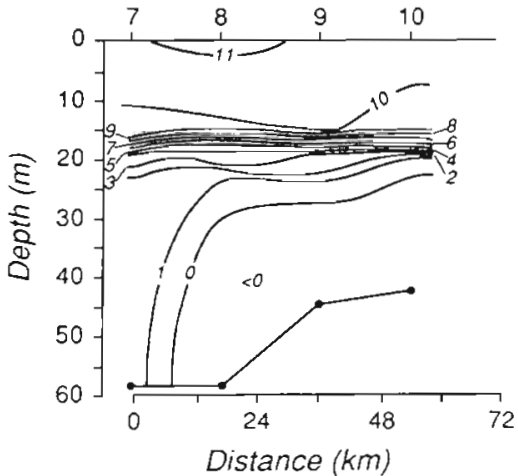

Temperature $\left({ }^{\circ} \mathrm{C}\right)$

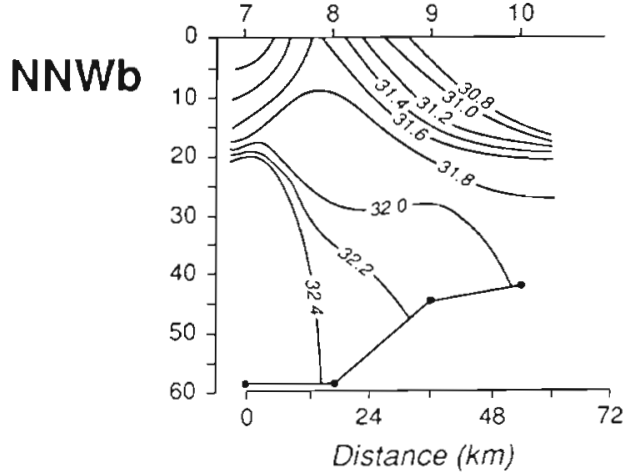

Salinity (ppt)
Fig. 7. Temperature and salinity sections along the west-southwest (20 August) and northnorthwest cruise tracks. NNWa $=22$ August, $N N W b=26$ August 1987 (see also Fig. 1) regimes elsewhere, although generally at longer time scales (i.e. days to weeks instead of hours; Burger \& Powell 1990, Piatt et al. 1990). Similar to our findings (Fig, 6), other investigators in the Bering Sea have found that some alcids (murres) form feeding aggregations at offshore sites primarily during limited phases of the tidal cycle (Coyle et al. 1992).

Another task of PCA, reducing large numbers of variables to only a few common variables, was only marginally successful in this case. Part of the reason may be the high cut-off point $(90 \%)$ used for component retention (we had no a priori basis for excluding potentially relevant niche dimensions in an exploratory analysis), Many of the original variables were chosen deliberately because they were likely to represent different attributes of the marine environment. We expected that water masses, tidal variability, and weather conditions are truly distinct phenomena, and thus unlikely to be mathematically correlated. Our results do suggest that in relatively complex marine environments such as the northern Bering Sea, the number of variables studied may need to be increased, or employed with greater resolution, so that numerical models can account for seabird abundances (e.g. Kinder et al. 1983) and construct representative niche dimensions (Ribic \& Ainley 1988/1989). 
Species interactions were of secondary importance relative to associations between species and environmental factors. An expectation arising from competition is that negative associations will be more evident among the small, plankton-feeding auklets, or among the more piscivorous murres and puffins, than between these groups (Bédard 1976). We failed to find strong negative interactions (Table 4) among alcid taxa sharing similar feeding strategies, food sources, or body size (Table 1). Indeed, components describing species interactions typically contrasted alcid taxa with the most dissimilar habits: puffins versus crested auklets, pigeon guillemot and parakeet auklet versus horned puffin, and murres and tufted puffin versus least auklet. Only PC10 illustrated a negative association between similar alcids, i.e. the plankton-feeding least and parakeet auklet. Even this interaction was rendered ambiguous by a stronger negative association between pigeon guillemot and parakeet auklet than between the 2 planktivores (Table 3 ).

Using presence/absence data as dependent variables, Schoener \& Adler (1991) found that species interactions became substantially more negative by taking habitat relationships into account during simultaneous analyses of habitat-by-species and speciesby-species associations. They also found that compound variables from PCA gave weaker trends than 'raw' habitat variables. In our study, correlations of compound variables and species abundances were generally stronger than between the original variables (cf. correlations of species with environmental variables in Appendix 1 to species' loadings in Table 3). Although superficially similar, our use of PCA with continuously varying values (species abundances) as dependent variables is not strictly analogous to the novel multivariate method used by Schoener \& Adler (1991) wherein logistic regression was combined with multiway-contingency-tables, Given that a variety of dependent variables have been employed in community analyses (i.e. counts of individuals, numbers per unit effort, or presence/absence), outcomes generated from different exploratory statistical methods would be worthy of further investigation. In a study of seabird-habitat relationships in the Antarctic, Ainley et al. (1994) found that parallel runs with canonical correlation and correspondence analyses gave similar results.

Alternatively, the scale chosen for our analysis may have affected the detection of species' associations. We used $0.3 \times 3.0 \mathrm{~km}$ transects as sites in our PCA, a common sampling scale for marine studies of seabirds (Tasker et al. 1984). As a consequence, linear scales ( 3 to $110 \mathrm{~km}$ ) encompassed spatial dimensions ranging from behavioral interactions among individual seabirds (Haney et al. 1992) up to linear distances traveled by birds commuting from breeding colonies (as much as $200 \mathrm{~km}$; Gaston \& Nettleship 1981). Our analysis was thus unable to resolve potential resource dimensions or species interactions above or below these spatial thresholds. Bédard (1976) recognized this as a 'sorting' problem when critiquing Cody's (1973) explanation for alcid coexistence. When sample units are based on integrated information (e.g. individuals per unit area), such arbitrary sorting is difficult to circumvent completely. If sampling units are sufficiently large, overlap among jointly occurring taxa is the likely outcome $_{i}$ if units are small enough, segregation is favored. Conducting analyses across several scales has been advocated as a solution to this predicament (e.g. Piatt 1990), but this practice results in untested geometric assumptions about the theoretical significance of chord lengths used to identify aggregations (see Haney \& Solow 1992).

Our study further suggests that without adequate measurement, niches of seabirds could be easily underdefined. Prey preferences are but one means of achieving resource partitioning in marine vertebrates. Differences in resource use are often more conspicuous in habitat, for example (Sano 1990 for marine fishes; Diamond 1983, Ainley et al. 1992 for seabirds). In 1 long-term study, Ainley \& Boekelheide (1990) identified at least 3 modes for segregation in the seabird community breeding at the Farallon Islands, California, USA: water mass type, breeding substrate, and access to prey via vertical stratification in depth. Even during El Niño 'crunch' years with limited food supplies, diet composition was 'relatively unimportant itself as a structuring factor' (Ainley \& Boekelheide 1990 , p. 365). Analyses of stable isotopes $\left(\delta^{13} \mathrm{C}\right.$ and $\delta^{15} \mathrm{~N}$ ) also show considerable overlap in trophic positions occupied by alcids when their diets are integrated over time (Hobson 1990, Hobson \& Welch 1992). When comparisons are expanded across years or geographic sites, convergence in both trophic position and prey selection can be detected in sympatric alcids sharing similar body morphology (e.g. common and thick-billed murres; see Ogi et al. 1985, Sanger 1987, Erikstad \& Vader 1989).

Cody's (1973) model for coexistence relied upon a concept of linear segregation. Here, we found that neither macro-habitats used for foraging nor alcid distributions themselves could be related simply to radial zones defined by distance. Taken alone, foraging distance generally cannot account for habitat preferences of seabirds (e.g. Kinder et al. 1983, Ainley \& Boekelheide 1990). In subpolar waters of the Bering Sea, substantial changes in location and lateral extent of water masses (Hunt et al. 1990), pycnocline topography (Haney 1991), and condition of the sea surface microhabitat (Fig. 4) over time limit the utility of theoretical 
models reliant upon distance assumptions. For example, a hinterland model (Cairns 1989) relates seabird colony size to the size of the area circumscribing waters within the colony's foraging range used by commuting birds. As later ammended by Cairns (1992), the relation between foraging area and amount of food availability within it breaks down if advective replenishment occurs. Such dynamic change in foraging 'substrate' is the rule in Anadyr Strait (Figs. 2, 4 \& 7). Springer et al. (1987) calculated that prey production for seabirds in the northern Bering Sea exceeds energetic requirements by a factor of 8 ; plankton-feeding alcids extract less than $0.4 \%$ of the daily influx of oceanic copepods swept through Anadyr Strait between July and September (Springer et al. 1989: 383). We doubt whether either prey or space for foraging (see Ainley \& Boekelheide 1990, p. 380) can be readily invoked as limiting resources for seabird communities situated in such favorable environmental settings.

In order to test formally the mechanisms responsible for coexistence in this group, longer investigations are desirable. In our study area, niche dimensions for the alcid community at St. Lawrence Island would require expansion to include affinities for sea ice during other seasons (large- but not small-bodied alcids occur in heavy Bering Sea pack ice; Everett et al. 1989). Persistence and resilience of this 'structure' could also be tested across time, as has been done for fish communities (Grossman 1986). We make no assumptions that 'structure' observed during our study period is typical of all years or regions, nor do we assume that alcid coexistence itself results from deterministic and not stochastic causes (see Grossman 1982). Any long-term study of coexistence should, however, take care to employ an appropriate sampling design that accounts for the kinds and magnitudes of environmental variability we observed in this study.

We argue that partitioning at sea among the Alcidae, whatever its ultimate origin, is likely to operate along multiple resource dimensions. Resources defined by environmental variability, although perhaps unconventional compared to traditional axes defined by diet, are nevertheless part of the ecosystems inhabited by these seabirds. As in other marine vertebrates (coral reef assemblages; Sano 1990), mechanisms influencing the structure of alcid communities may vary geographically, a point emphasized by Bédard (1976). Coexistence among alcids at St. Lawrence Island is facilitated through advection, air-sea interactions, and variable surface and subsurface structure in the adjacent Bering Sea, all of which create a complex spatio-temporal mosaic of available niche dimensions for this seabird community.

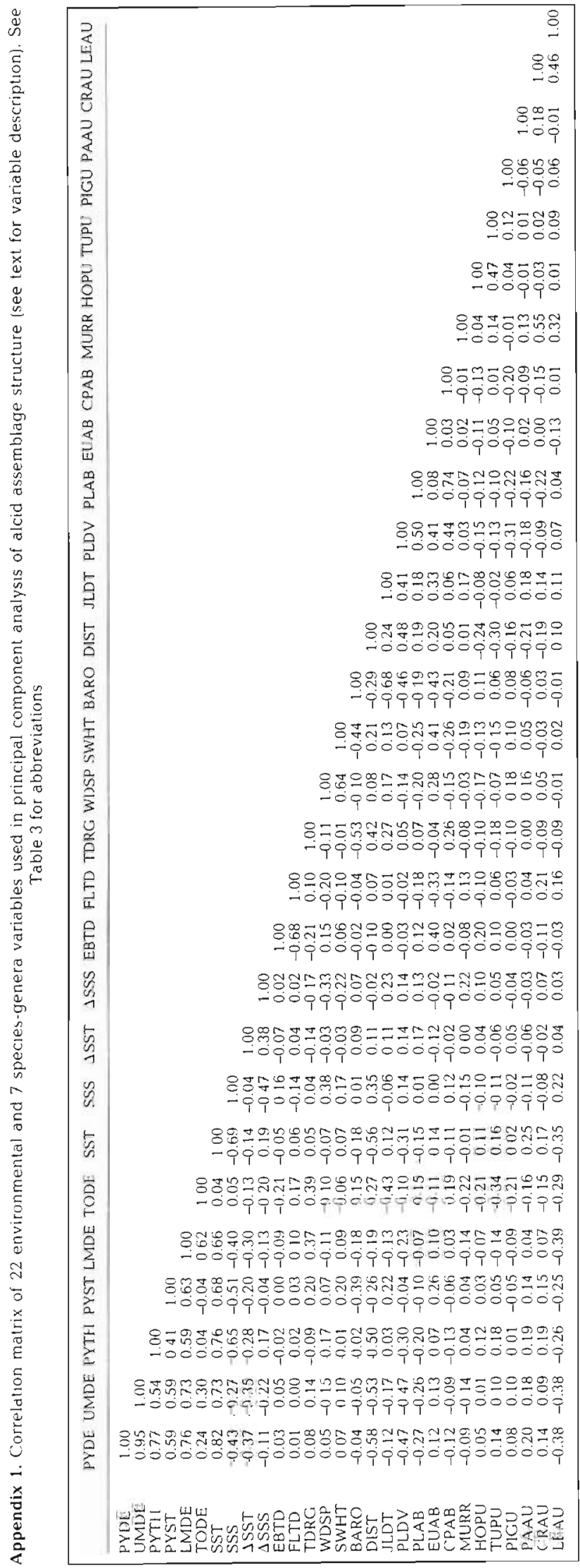


Acknowledgements. This study was funded partially by the Minerals Management Service (MMS), U.S. Dept of the Interior (DOI), through an Intra-agency Agreement (No. 14-120001-30391) with U.S. Fish and Wildlife Service (USFWS), U.S. DOI, as part of the MMS Alaska Environmental Studies Program. Additional support was provided by NSF-DPP project ISHTAR (No. 8605659), the Alaska Fish and Wildlife Research Center, and the Alaska Maritime National Wildlife Refuge, USFWS. John Martin, Captain Al Bayer, and the crew of the MV 'Eagle-Tiglax' provided substantial logistical assistance. G. Lingle, C. Swafford, A.-M. Furman, R. Dwork, S. Hatch and $\mathrm{J}$. Wells assisted at sea. The Institute of Marine Science, University of Alaska, Fairbanks, provided access to computer routines for hydrographic analyses. The Sivuqaq and Savoonga Native Corporations and town councils of Gambell and Savoonga granted permission to work at St. Lawrence Island. Personnel from the Arctic Environmental Information and Data Center, Univ. of Alaska, Anchorage, provided data on the tidal regimes of the northern Bering Sea. Jack Cook, Woods Hole Oceanographic Institution, prepared several of the figures. Analyses and manuscript preparation were supported through Pennsylvania State University. A seminar series hosted by G. D. Grossman and G. S. Helfmann, Univ. of Georgia, provided a forum for debate of ecological communities and an introduction to the alcid controversy. D. G. Ainley, A. N. Golovkin, G. D. Grossman and several anonymous referees provided many helpful comments on earlier drafts of the manuscript.

\section{LITERATURE CITED}

Ainley, D. G., Boekelheide, R. J. (1990). Seabirds of the Farallon Islands: ecology, dynamics and structure of an upwelling-system community. Stanford Univ. Press, Stanford

Ainley, D. G., Ribic, C. A., Fraser, W. R. (1992). Does prey preference affect habitat choice in Antarctic seabirds? Mar. Ecol. Prog. Ser. 90: 207-221

Ainley, D. G., Ribic, C. A., Fraser, W. R. (1994). Ecological structure among migrant and resident seabirds of the Scotia-Weddell confluence region. J. Anim. Ecol. 63; in press

Ashmole, N. P. (1963). The regulation of numbers of tropical oceanic birds. Ibis $103 \mathrm{~b}: 458-473$

Bédard, J. (1969a). Adaptive radiation in the Alcidae. Ibis 111: $189-198$

Bédard, J. (1969b). Feeding of the least, crested and parakeet auklets around St. Lawrence Island, Alaska. Can. J. Zool. 47: $1025-1050$

Bédard, J. (1969c). The nesting of the crested, least, and parakeet auklets on St. Lawrence Island, Alaska. Condor 31: 386-398

Bédard, J. (1976). Coexistence, coevolution and convergent evolution in seabird communities: a comment. Ecology 57 : $177-184$

Birkhead, T. R., Furness, R. W. (1985). Regulation of seabird populations. In: Sibly, R. M., Smith, R. H. (eds.) Behavioral ecology. Blackwell, Oxford, p. 147-168

Birkhead, T. R., Nettleship, D. N. (1987). Ecological relationships between common murres, Uria aalge, and thickbilled murres, Uria Iomvia, at the Gannet Islands, Labrador. III. Feeding ecology of the young. Can. J. Zool. 65: $1638-1649$

Birt, V. L., Birt, T. P., Goulet, D., Cairns, D. K., Montevecchi, W. A. (1987). Ashmole's halo: direct evidence for prey depletion by a seabird. Mar Ecol. Prog. Ser. 40: 205-208

Bradstreet, M. S. W. (1979). Thick-billed murres and black guillemots in the Barrow Strait area, N.W.T., during spring: distribution and habitat use. Can. J. Zool. 57 1789-1802

Bradstreet, M. S. W. (1980). Thick-billed murres and black guillemots in the Barrow Strait area, N.W.T., during spring: diets and food availability along ice edges. Can. J. Zool. 58: 2120-2140

Bradstreet, M. S. W. (1982). Pelagic feeding ecology of dovekies Alle alle in Lancaster Sound and western Baffin Bay. Arctic 35: 126-140

Bradstreet, M. S. W., Brown, R. G. B. (1985). Feeding ecology of the Atlantic Alcidae. In: Nettleship, D. N., Birkhead, $T$ R. (eds.) The Atlantic Alcidae. Academic Press, Orlando, p. 263-318

Burger, A. E., Powell, D. W. (1990). Diving depths and diet of Cassin's auklet at Reef Island, British Columbia. Can. J. Zool. 68: 1572-1577

Burger, A. E., Simpson, M. (1986). Diving depths of Atlantic puffins and common murres. Auk 103: 828-830

Cairns, D. K. (1989). The regulation of seabird colony size: a hinterland model. Am. Nat. 134: 141-146

Cairns, D. K. (1992). Population regulation of seabird colonies. In: Power, D. M. (ed.) Current ornithology, Vol. 9. Plenum Press, New York, p. 37-61

Coachman, L. K., Aagaard, K., Tripp, R. B. (1975). Bering Strait: the regional physical oceanography. Univ. of Washington Press, Seattle

Cody, M. L. (1973). Coexistence, coevolution and convergent evolution in seabird communities. Ecology 54: 31-44

Coyle, K. O., Hunt, G. L. Jr, Decker, M. B., Weingartner, T. J. (1992). Murre foraging, epibenthic sound scattering and tidal advection over a shoal near St. George Island, Bering Sea. Mar. Ecol. Prog. Ser. 83: 1-14

Day, R. H., DeGange, A. R., Divoky, G. J., Troy, D. M. (1988). Distribution and subspecies of the dovekie in Alaska Condor 90: 712-714

Diamond, A. W. (1983). Feeding overlap in some tropical and temperate seabird communities. Stud. Avian Biol. 8: 24-46

Diamond, J., Case, T. J. (eds.) (1986). Community ecology. Harper and Row, New York

Dinets, V. L. (1992). Probable nesting of the spectacled guillemot. In: Kondratiev, A. Y (ed.). Research on colonial seabirds of the USSR. Inst. Biol. Probl. North, Akad Nauk-Far Eastern Branch, Magadan, p. 33 (in Russian)

Doherty, P. J., Williams, D. McB. (1988). The replenishment of coral reef fish populations. Oceanogr. Mar. Biol. A. Rev. 26: $487-551$

Duffy, D. C., Todd, F. S., Siegfried, W. R. (1987). Submarine foraging behavior of alcids in an artificial environment. Zoo Biol. 6: 373-378

Eberhardt, L. L., Thomas, J. M. (1991). Designing environmental field studies. Ecol. Monogr. 61:53-73

Erikstad, K. E., Vader, W. (1989). Capelin selection by common and Brunnich's guillemots during the prelaying season. Ornis Scandinavica 20: 151-155

Everett, W. T., Ward, M. L, Brueggeman, J. J. (1989). Birds observed in the central Bering Sea pack ice in February and March 1983. Le Gerfaut 79: 159-166

Fay, F. H., Cade, T. J. (1959). An ecological analysis of the avifauna of St. Lawrence Island, Alaska. Univ. Calif. Publ. Zool. 63: 73-150

Flint, V. E., Golovkin, A. N. (eds.) (1990). Birds of the U.S.S.R., Shorebirds: Family Alcidae. Akad. Nauk, Moscow (in Russian)

Furness, R. W., Birkhead, T. R. (1984). Seabird colony distributions suggest competition for food supplies during the breeding season. Nature 311:655-656 
Gaston, A. J., Nettleship, D. N. (1981). The thick-billed murres of Prince Leopold Island - a study of the breeding biology of a colonial, high arctic seabird. Monogr. Ser. Can. Wildl. Serv. 6: 1-350

Golovkin, A. N., Zelikman, E. A., Georgiev, A. A. (1972). Biology and feeding connections of little auks Plotus alle with a pelagic association in the north of Novaya Zemlya. In: Golovkin, A. N. (ed.) Pecularities of biological productivity of waters near bird bazaars in the north of Novaya Zemlya. Akad. Nauk, Leningrad, p. 78-84 (in Russian)

Grebmeier, J. M., McRoy, C. P., Feder, H. M. (1988). Pelagicbenthic coupling on the shelf of the northern Bering and Chukchi seas. I. Food supply source and benthic biomass. Mar. Ecol. Prog. Ser. 48: 57-67

Grossman, G. D. (1982). Community regulation and patterns of resource partitioning. In: Cailliet, G., Simenstad, C. (eds.) Proceedings of the third Pacific technical workshop on fish food habit studies. Washington Sea Grant, Seattle, p. $166-177$

Grossman, G. D. (1986). Food resource partitioning in a rocky intertidal fish assemblage. J. Zool., Lond. B 1. 317-355

Grossman, G. D., Nickerson, D. M., Freeman, M. C. (1991). Principal component analyses of assemblage structure data: utility of tests based on eigenvalues. Ecology 72 : $341-347$

Haney, J. C. (1991). Influence of pycnocline topography and water column structure on marine distributions of alcids (Aves: Alcidae) in Anadyr Strait, northern Bering Sea, Alaska. Mar. Biol. 110: 419-435

Haney, J. C., Fristrup, K. M., Lee, D. S. (1992). Geometry of visual recruitment by seabirds to ephemeral foraging flocks. Ornis Scand. 23:49-62

Haney, J. C., Solow, A. R. (1992). Analyzing quantitative relationships between seabirds and marine resource patches. In: Power, D. M. (ed.) Current ornithology, Vol. 9. Plenum Press, New York, p. 105-162

Hansell, D. A., Goering, J. J., Walsh, J. J., McRoy, C. P., Coachman, L. K., Whitledge, T. E. (1989). Summer phytoplankton production and transport along the shelf break in the Bering Sea. Cont. Shelf Res. 12: 1085-1104

Harrison, N. M. (1990). Gelatinous zooplankton in the diet of the parakeet auklet: comparisons with other auklets. In Sealy, S. G. (ed.) Auks at sea. Stud. Avian Biol. 14 $114-124$

Highsmith, R. C., Coyle, K. O. (1990). High productivity of northern Bering Sea amphipods. Nature 344: 862-864

Hobson, K. A. (1990). Stable isotope analysis of marbled. murrelets: evidence for freshwater feeding and determination of trophic level. Condor 92: 897-903

Hobson, K. A., Welch, H. E. (1992). Determination of trophic relationships within a high Arctic marine food web using $\delta^{13} \mathrm{C}$ and $\delta^{15} \mathrm{~N}$ analysis. Mar. Ecol. Prog. Ser. 84: 9-18

Hunt, G. L. Jr, Harrison, N. M., Cooney, R. T (1990). The influence of hydrographic structure and prey abundance on foraging least auklets. In: Sealy, S. G. (ed.) Auks at sea Stud. Avian Biol. 14: 7-22

Hunt, G. L. Jr, Harrison, N. M., Piatt, J F. (1993). Foraging ecology as related to the distribution of planktivorous auklets in the Bering Sea. In: Vermeer, K., Bnggs, K. T. Morgan, K. H., Siegel-Causey, D. (eds.) The status, ecology, and conservation of marine birds of the North Pacific Canadian Wildlife Service, Ottawa, p. 18-26

Jolliffe, I. T (1986). Principal component analysis. SpringerVerlag, New York

Kinder, T H., Hunt, G. L. JI, Schneider, D., Schumacher, J. D (1983). Correlations between seabirds and oceanic fronts around the Pribilof Islands, Alaska. Estuar. coast. Shelf
Sci. 16: $309-319$

Konyukhov, N. B. (1990). Black Guillemot [Cephus grylle] in the Chukot Peninsula. In: Kondratiev, A. Y. (ed.) Research on colonial seabirds of the USSR. Inst. Biol Probl. North Akad. Nauk-Far Eastern Branch, Magadan, p. 25-26 (in Russian)

Konyukhov, N. B. (1992). Occurrence of the Kittlitz's murrelet in eastern Chukotka waters. In: Kondratiev, A. Y (ed.) Research on colonial seabirds of the USSR. Inst. Biol Probl. North, Akad. Nauk-Far Eastern Branch, Magadan, p. 31-33 (in Russian)

Lack, D. (1966). Population studies of birds. Oxford Univ. Press, Oxford

Lack, D. (1967). Interrelationships in breeding adaptations as shown by marine birds. In: Proc. XIV Inter. Ornithol. Congr. p. $3-42$

McRoy, C. P., Goering, J. J., Shields, W. S. (1972). Studies of primary production in the eastern Bering Sea. In: Takenouti. A. Y. (ed.) Biological oceanography of the northern Pacific Ocean. Idemitsu Shoten, Tokyo, p. 199-216

Motoda, S., Minoda, T (1974). Plankton of the Bering Sea. In: Hood, D. W., Kelly, E. J. (eds.) Oceanography of the Bering Sea. Occasional Publ. No. 2, Inst. Mar. Science, Univ. Alaska, Fairbanks, p. 207-241

Nettleship, D. N., Birkhead, T. R. (eds.) (1985). The Atlantic Alcidae. Academic Press, Orlando

Ogi, H., Tanake, H., Tsujita, T (1985). The distribution and feeding ecology of murres in the northwestern Bering Sea. J. Yamashina Inst. Ornithol. 17: 44-56

Piatt, J. F. (1990). The aggregative response of common murres and Atlantic puffins to schools of capelin. In: Sealy, S. G. (ed.) Auks at sea. Stud. Avian Biol. 14: 36-51

Piatt, J. F., Hatch, S. A., Roberts, B. D., Lidster, W. L., Wells, J. L., Haney, J. C. (1988). Populations, productivity, and feeding habits of seabirds on St. Lawrence Island, Alaska. U.S. Fish Wildl. Serv. Final Rept MMS 88-0022, Anchorage

Piatt, J F., Nettleship, D. N. (1985). Diving depths of four alcids. Auk 102: 293-297

Piatt, J. F., Roberts, B. D., Hatch, S. A. (1990). Colony attendance and population monitoring of least and crested auklets on St. Lawrence Island, Alaska. Condor 92: $97-106$

Ribic, C. A., Ainley, D. G. (1988/1989). Constancy of seabird species assemblages: an exploratory look. Biol. Oceanogr. 6: $175-202$

Roby, D. D., Brink, K. L., Nettleship, D. N. (1981). Measurements, chick meals and breeding distribution of dovekies (Alle alle) in northwest Greenland. Arctic 34: 241-248

Roseneau, D. G., Springer, A. M., Murphy, E. C., Springer, M. I. (1985). Population and trophic studies of seabirds in the northern Bering and eastern Chukchi seas, 1981 In: Environmental assessment of the Alaskan continental shelf, Vol. 30. BLM/NOAA OSCEAP, Boulder, CO, p. 1-55

Sale, P. F. (1978). Coexistence of coral reef fish - a lottery for l.ving space. Environ. Biol. Fish. 3: 85-102

Sale, P. F. (1980). The ecology of fishes on coral reefs Oceanogr. mar. Biol. A. Rev. 18: 367-421

Sambrotto, R. H., Goering, J. J., McRoy, C. P. (1984). Large yearly production of phytoplankton in western Bering Strait. Science 225: 1147-1150

Sameoto, D. D., Jaroszynski, L. O. (1969). Otter surface sampler: a new neuston net. J. Fish. Res. Bd Canada 26: $2240-2244$

Sanger, G. A. (1987). Winter diets of common murres and marbled murrelets in Kachemak Bay, Alaska. Condor 89: $426-430$ 
Sano, M. (1990). Patterns of habitat and food utilization in two coral-reef sandperches (Migiloididae): competitive or noncompetitive coexistence? J. exp. mar Biol. Ecol. 140: 209-223

Schawer, A. E. S. (1992). Associations between seabirds and water masses in the northern Bering Sea. In: Nagel, P. A. (ed.) Results of the third joint US-USSR Bering and Chukchi seas expedition (BERPAC), summer 1988. U.S. Fish and Wildl. Serv., Washington, DC, p. 388-398

Schoener, T W., Adler, G. H. (1991). Greater resolution of distributional complementarities by controlling for habitat affinities: a study with Bahamian lizards and birds. Am. Nat. 137: 669-692

Sealy, S. G. (1968). A comparative study of breeding ecology and timing in plankton-feeding alcids (Cyclorrhynchus and Aethia spp.) on St. Lawrence Island, Alaska. M.Sc. thesis, Univ. British Columbia, Vancouver

Sealy, S. G. (1973). Breeding biology of the horned puffin on St. Lawrence Island, Bering Sea, with zoogeographic notes on the North Pacific puffins. Pacif. Sci. 27: 99-119

Sealy, S. G. (ed.) (1990). Auks at sea. Stud. Avian Biol. 14

Sealy, S. G., Bédard, J. (1973). Breeding biology of the parakeet auklet (Cyclorrhynchus psittacula) on St. Lawrence Island, Alaska Astarte 6: 59-68

Searing, G. F. (1977). Some aspects of the ecology of cliffnesting seabirds at Kongkok Bay, St. Lawrence Island, Alaska, during 1976. In: Environmental assessment of the Alaskan Continental Shelf, Vol 5. BLM/NOAA OCSEAP, Boulder, Co, p. 263-412

Smith, G. R., Taylor, J. N., Grimshaw, T W. (1981). Ecological survey of fishes in the Raisin River drainage, Michigan. Mich. Academ. 13: 275-305

Snedecor, G. W., Cochran, W. G. (1980). Statistical methods Iowa State Univ. Press, Ames

Sowls, A. L., Hatch, S. A., Lensink, C. J. (1978). Catalog of Alaskan seabird colonies. U.S. Fish and Wildl. Serv., Anchorage

This article was submitted to the editor
Spring, L. (1971). A comparison of functional and morphological adaptations in the common murre (Uria aalge) and thick-billed murre (Uria lomvia). Condor 73: 1-27

Springer, A. M., McRoy, C. P., Turco, K. R. (1989). The paradox of pelagic food webs in the northern Bering Sea. Il Zooplankton communities. Cont. Shelf Res. 9: 359-386

Springer, A. M., Murphy, E. C., Roseneau, D. G., McRoy, C. P., Cooper, B. A. (1987). The paradox of pelagic food webs in the northern Bering Sea. I. Seabird food habits. Cont. Shelf Res. 7: 895-911

Strauch, J. G. (1985). The phylogeny of the Alcidae. Auk 102: $520-539$

Strong, D. R., Simberloff, D., Abele, L. G., Thistle, A. B. (eds.) (1984). Ecological communities: conceptual issues and the evidence. Princeton Univ. Press, Princeton

Tasker, M. L., Jones, P. H., Dixon, T., Blake, B. F. (1984). Counting seabirds at sea from ships: a review of methods employed and a suggestion for a standardized approach. Auk 101: 567-577

Vermeer, K., Sealy, S. G., Sanger, G. A. (1987). Feeding ecology of the Alcidae in the eastern North Pacific. In: Croxall, J. P. (ed.) Seabirds: feeding ecology and role in marine ecosystems. Cambridge Univ. Press, Cambridge, p. $189-22$

Weimerskirch, H., Bartle, J. A., Jouventin, P., Stahl, J. C. (1988). Foraging ranges and partitioning of feeding zones in three species of southern albatrosses. Condor 90:214-219

Wellington, G. M., Victor, B. C. (1984). El Niño mass coral mortality: a test of resource limitation in a coral reef damselfish population. Oecologia 68: 15-19

Wiens, J. (1977). On competition and variable environments. Am. Sci. 65: 590-597

Wilkinson, L. (1989). SYSTAT: the system for statistics. SYSTAT Inc., Evanston, IL

Wolda, H. (1989). Comment on the article 'On testing temporal niche differentiation in carabid beetles' by $M$. Loreau and the 'Comment on the article of M. Loreau' by P. J. den Boer. Oecologia 81. 99

Manuscript first received: August 4, 1993

Revised version accepted: October 18, 1993 